\title{
EARLY WARNING INDICATORS STUDY OF BANK RUNS IN INDONESIA : MARKOV-SWITCHING APPROACH
}

\author{
Iskandar Simorangkir ${ }^{1}$
}

\begin{abstract}
A run on a particular bank can lead to a banking crisis if it spreads to other banks (contagious effect). In the case of Indonesia, bank runs have also reoccurred time and again. In 1992, bank runs affected several national banks, subsequently precipitating the liquidation of one bank. Then in 1997/1998, bank runs developed into the worst banking crisis ever witnessed in the banking history of Indonesia. Considering the extent of losses attributable to bank runs and the banking crisis, extensive studies on the early warning indicators of bank runs are urgently required to prevent future bank runs and banking crises. This paper aims to comprehensively analyse the early warning indicators of bank runs for all banks in Indonesia, both during the sample period of 1990-2005 as well as during the banking crisis in 1997-1998. The study of early warning indicators of bank runs uses the Markov-Switching model. To calculate the transition probability from a tranquil state to a state of bank run uses the Markov-Switching process through an auto-regressive approach. The change in deposits held at each bank is used as a variable of bank runs. The results of Markov-Switching (MS) show that the MS model is robust as an early warning indicator of bank runs. This is reflected by testing, which was performed on the actual incident of 102 banks, showing that the MS model only produced false signals an estimated $0.69 \%-2.08 \%$ of the time.
\end{abstract}

Keywords: Bank Runs, Early Warning Indicators, Markov-Switching

JEL Classification: C22, G21

1 Director / Head of Economic Research Group Bank Indonesia. The authors would like to thank the participants of the International Conference on Economic Modelling-Ecomod 2012, Seville, Spain, held July 4 to 6, 2012. Also thank you to Professor Rustam Didong, Dr. Muliaman D. Hadad and Dr. Sugiharso Safuan for their valuable comments. The views of this paper represent the personal opinions of the author and do not reflect the opinions of BI. 


\section{INTRODUCTION}

Bank runs occur because of vulnerability to the withdrawal of bank customers. The vulnerability is related to the business activities of banks that transforms short-term liabilities, such as demand deposits, savings deposits and assets into the longer-term liabilities, such as credit. Under these conditions, banks are faced with the problem of maturity missmatch which makes it vulnerable to a massive with drawal of funds (bank runs) by customers due to limited liquid assets owned by customers. The withdrawal of massive public deposits is mainly due to the decline of public confidence in the banks. Decline in confidence in the bank point to internal factors, such as the decline in bank performance, as well as other external factors, such as the deterioration of the economy resulting in acontagion effect.

Empirical evidence suggests that the impact of bank runs can negatively affect the country's economy especially if widespread resulting in a banking crisis. A banking crisis stemming from bank runs leads to a disconnection of intermediation financing and brings a business to a standstill. Cessation of funding sources can result in business activity or production halted and eventually lead to contraction or slowdown and rising unemployment. From the fiscal side, a banking crisis will lead to higher cost recovery for bank restructuring. All these recovery costs will ultimately be borne by the tax payer or the public.

The experience of the 1997/1998 Asian crisis showed that the banking crisis was one of the main factors that resulted in the severe economic contraction in Asian countries. The Indonesian economy was an economy that contracted the most high, reaching $-13.1 \%$ in 1998. Meanwhile, economic growth in Thailand, Malaysia, South Korea and the Philippines in the same year contracted by $10.5 \%, 7.4 \%, 6.9 \%$ and $0.6 \%$, respectively. Also, the cost of restructuring from the banking crisis reached $45 \%$ of gross domestic product for Indonesia, $15 \%$ to $12 \%$ for Korea and Malaysia (Lindgren et. All. 1999).

Given the incidence of bank runs can be repeated and harm the economy, its impact will require in-depth study on the development of models of early indicators to prevent bank runs. In general, research on early warning indicators (EWI) uses two main models, namely the signal extraction model and econometrics model.

The signal extraction model uses a non-parametric approach by observing the behavior of particular variables before and after crisis. The model is widely used and is used as a reference study by Kaminsky $(1998,1999)$ as an early warning indicator of exchange rate and banking crises, and Kaminsky, Lizondo and Reinhart (1998) as an EWS for exchange rate crisis. Other models used to detect banking crisis are Econometric models, one of which is the logit model. Demirgüc-Kunt and Detragiache (1998) used a logit model to detect the onset of a banking crisis. In this approach, the possibility of a crisis is assumed to be a function of the explanatory variable vector, where the dependent variable is 0 if no crisis and 1 if a crisis occurs.

Research on early warning indicators (EWI) were conducted by several authors. The research of Agung et al. (2003) and Dewati et al. (2004) discussed the early warning indicators of 
exchange rate crisis and the financial crisis in Indonesia using the signal extraction model. This approach has several problems, namely the value relating to the delimitation of the crisis (threshold) and duration of the crisis that was done arbitrarily. Bank Indonesia (2003a, 2003b and 2003c) research studies of EWI in the stability of the financial system used discriminant analysis and logistic regression, but did not do research on bank runs. Bank Indonesia (2004a) examined the bankruptcy prediction model of commercial banks in Indonesia by using factor analysis and logistic regression, whereas EWlbank runswere not discussed.

With this background, this study will try to develop early warning indicators to detect the possibility of bank runs using the markov-switching model. The second part of this paper discusses the theoretical foundation and some empirical results of previous studies. The third section describes the overview of the performance of national banks during the crisis and empirical models used. Empirical results of the study will be presented in the fourth section, while the final section provides conclusions and suggestions to prevent bank runs.

\section{THEORY}

\subsection{Bank Runs and Early Warning Indicators}

Early warning indicators for individual banks were built with earlier empirical studies conducted in the mid-1970s. Research by Gonzalez-Hermosillo (1999) concluded that the collapse of a bank would be due to liquidity, market and credit risk. These three factors can certainly influence the characteristics of individual banks and macroeconomic conditions. To capture the impact of different effects Gonzalez-Hermosillo (1999) estimated a regression model using several indicators of banking (as a proxy of market risk, credit risk, liquidity risk and moral hazard factor) together with regional and macroeconomic variables. The study explicitly investigated how the fall of an individual bank may be affected by the vulnerability of the financial sector as a whole (e.g., by considering contagion). Specifically, the study put the total ratio of credit to output as a measure of vulnerability of the banking sector in the regression.

In line with the research conducted by the U.S. Federal Deposit Insurance Corporation (FDIC) in the system indicators, Gonzalez-Hermosillo (1999) distinguished vulnerability indicators derived from the risk factors that lead to bank collapse. In general, an increase in non-performing loans and falling capital ratio (CAR) were signals before the banks crashed. But few think that these indicators were the main causes of the crisis in estimating the fall of banks. Some of the main points of the research allude to the higher property loans and interbank placementsas the greater the likelihood for the failure of a bank. Conversely the higher the acceptance of credit and the greater the share of securities that can be traded, the smaller the risk of a bank collapse. Meanwhile, the contagion factor influenced bank collapse in some cases, and the effect was very small. 
Meanwhile, Davis and Karim (2007) stated that in a study of early warning indicators (EWI) a right approach needed, among others, by using logit and signal extraction. Different methods used to produce performance indicatorspredicted crisis differently. The logit method is considered more feasible for use on a global early warning system (EWS), while the signal extraction is more appropriate for country-specific EWS. Along with the development and liberalization of the financial sector ${ }^{2}$, the use of EWS for crisis prevention is needed.

Demirguc-Kunt and Detragiache (1999) conducted a study to predict the probability of a banking crisis that was intended as a tool to monitor the vulnerability of the banking sector. Their research used multivariate logit with panel data, using variables that reflect macroeconomic and financial sector. Variables that reflect macroeconomic conditions include: GDP growth, changes in the terms of trade, exchange rate depreciation, inflation and the budget surplus / GDP. Meanwhile, the variables that reflect the characteristics of the financial sector, namely: M2 / reserves and bank credit growth rate with a lag of two periods. In addition they used GDP per capita as a proxy for the structural characteristics of the economy. The study results showed that a low GDP growth, high real interest rates, high inflation, and strong credit growth in the past as well as the magnitude of the ratio of $\mathrm{M} 2$ to reserves together have led to more banking crisis. Meanwhile, the variable exchange rate depreciation, terms of trade, and the budget surplus to GDP did not seem to be significant.

The use of probit or logit regression, and approach as an indicator of early warning signals has some disadvantages. First, the determination of the date of commencement of the crisis is anarbitrary determination which tends to be late (Von Hagen and Ho, 2003). Secondly, the early indicators of banking using the ratio deviation (noise) as a signal which was a minimum and has limitations. These limitations led to the delineation of the banking crisis index value (threshold) conducted arbitrarily. Some researchers defined different thresholds without providing a strong argument, as Eichengreen, Rose and Wyplosz (1996) who defined a crisis threshold of 1.5 standard deviations from the mean, while Kaminsky and Reinhart (1999) defined a crisis threshold for 3 standard deviations above average (mean). In addition, the threshold of the crisis also greatly depends on the amount of sampling that was taken. The addition of data or an extended period of time can change the crisis limit. The third weakness is the crisis index transformation into binary numbers may result in the loss of relevant information.

In line with weaknesses using the probit / logit approach and the arbitrary use of the boundary (threshold) crisis, there is growing use of the Markov-Switching models in studying the exchange rate crisis and the banking crisis. The use of this model is not only limited to be used to identify periods of crisis but also to estimate when the banking crisis could happen. The use of Markov-Switching in analyzing or detecting the occurrence of banking crises has several

2 Liberalization of the financial sector according to Karim and Davis (2007) is the freedom given to a financial institution from market mechanisms to remove barriers from the Government. 
advantages. First, the crisis index limit value (threshold) is an endogenous variable or in other words the crisis period and the duration of the crisis is part of the estimated results. In this approach, the economy is assumed to be in a tranquil state or state crisis. Thus, the second state is not observed directly, and both are latent variables. However, both these state indicators can be observed directly by looking at their behavior in the economy. Both states are different, with the crisis state having higher fluctuating values than the tranquil state (normal time). The transfer of values from one state to another state depends on transition probability. In accordance with the characteristics of Markov, the value of which will come in a state will depend on the current state. Thus, this model allows for the possibility of a state in crisis that can remain in a state of crisis.

The second advantage of the Markov switching model allows the use of a continuous dependent variable.The use of third-party funds or change the index to avoid the loss of information when data is transformed in the form of dummy variable. The third advantage of this model is its use to capture dynamic information of the crisis. Thus, this model can interpret the trend duration of the crisis period and the transition probabilities. The fourth advantage is the model can be used for non-linear behavior.

The use of Markov-Switching to detect exchange crisis and a banking crisis in recent years has increasingly developed because of the growing occurrence of flaws in the signal approach, i.e. the determination of the arbitrary threshold of crisis. Abiad (2003) using a MarkovSwitching approach examined early warning systems for possible exchange rate crisis in Asia. Based on these studies it was found that this model works well in detecting the exchange rate crisis in Asia. The model was able to detect two-thirds of the crisis period in the sample and resulted in fewer the false signals compared to the signal approach model. Research by AlvarezPlata and Schrooten (2003) and Ho (2004) also produced good results (robust) using the model in detecting the exchange rate crisis in Argentina and Asia, respectively.

Meanwhile, the use of Markov-Switching models applied to banking crisis using aggregate data was done by Ho (2004). The results showed that the model can detect a banking crisis in Asia. For Research in Indonesia, Agung et. al. (2003) developed an Early Detection System for predicting the exchange rate crisis and the banking crisis, by modifying the signal extraction model of Kaminsky, Lizondo, and Reinhart (1999). Modifications include trying to capture the abnormal behavior of the indicators used, not individually, but by using aggregate index. This is done since before the crisis indicators usually will move in the same direction. The variables used are: macroeconomic indicators (real appreciation of the domestic currency, foreign exchange $\mathrm{M} 2 /$ reserves) to predict the exchange rate crisis, and micro indicators of aggregate banking (net interest margin) to predict the banking crisis. The results showed that the signals generated from an early detection system showed relatively satisfactory results, i.e. the probability of accuracy of $67 \%$ and $90 \%$, respectively. 


\subsection{Development of the Banking Crisis}

At first the crisis that hit the Indonesian economy since 1997 is mainly triggered by the exchange rate. Pressure depreciation of the rupiah which is mainly derived from the contagion factor from Thailand Baht exchange rate crisis in July 1997. Effect of contagion is not only Indonesia but also struck quickly spread to other Asian countries, including the Philippines, Malaysia and South Korea. In order to prevent the national economy from deeper crisis as a result of the pressure of depreciation and capital outflow, the Government issued a package of economic policy in September 1997. Furthermore, the program expanded to stabilization and economic reform program supported by the IMF, World Bank and ADB formally in November 1997. As a manifestation of the implementation of the reform program in the financial sector in order to nourish the banking system, then on 1 November 1997 by 16 private banks were closed.

Closure of 16 banks led to bank runs on banks by the public perception quite unhealthy. Bank closure policy is supposed to nourish national banks the opposite result in massive withdrawals in banks and not the government. Massive withdrawal of funds is due the collapse of public confidence in the banking system due to the closure of the bank. The more widespread bank runs are also due to the weak financial performance of the bank, such as an increase in bad loans and declining rentability of the bank, due to business management that is not fully follow the healthy nature of corporate governance (Warjiyo, 2001 and Bank Indonesia, 1998²). In addition, the rapid depreciation of the rupiah resulted in ballooning bank debt denominated in dollars. This condition is further aggravated the absence of the guarantee program. In the midst of yet the presence and absence of a guarantee program information about the condition of banks (asymmetric information), bank customers, particularly customers' private bank, withdraw the funds on a large scale and are expected to shift to healthier banks and into safer assets (currency).

One month since the closure of 16 banks mentioned above (December 1997), the number of third-party funds contained in the national private commercial banks (BUSN) decreased by Rp 22.9 trillion (11.94\%). Generally begin withdrawing funds from bank closures and the withdrawal of the highest peak in December 1997 and January 1998. The recall was dropped since the government guarantee (blanket guarantee) in January 1998. However, in the event of social unrest in May 1998, the number of banks that experienced bank runs increased again.

Based on data from monthly reports (LBU) bank submitted to Bank Indonesia, massive withdrawals (bank runs) more common in non-foreign BUSN ${ }^{3}$, frozen bank activities ${ }^{4}$ and frozen bank operations ${ }^{5}$. Peak mass recall on Non forex BUSN in December 1997, January 1998 and May 1998. As an illustration, in December 1997, from 45 Non forex BUSN, 25 banks decreased

3 Annual Report of Bank Indonesia in 1997/1998.

4 Non forex BUSN is not allowed to conduct foreign exchange transaction in their business activities.

5 Frozen Bank operations (BBKU) is a bank whose business activities are suspended or are not allowed to conduct business activities temporarily or period of time. 
third party funds up to $10 \%, 17$ banks funding decreased by $20 \%, 13$ banks has decreased by 40 funds, 11 funds a bank has decreased by $60 \%$, and 6 banks of funds decreased to $80 \%$ of the total funds in the previous month.

As in non forex BUSN, bank runs occurred in banks with frozen business activities (BBKU) and banks with frozen bank operations (BBO). Biggest withdrawal occurred in November 1997 until January 1998, and March through May 1998. For example, in November 1998, from 40 BBKU banks decreased by 26 third-party funds up to $10 \%$ of the total deposits in the previous month, 14 banks of funds decreased by $20 \%$ compared to the previous month's total funding, and the two banks has decreased funding to $40 \%$ compared to the previous month. Bank runs in BBO is also not much different from BBKU. In January 1998, out of 10 BBO, 6 banks of thirdparty funds decreased to $20 \%$ and 4 banks decreased by $40 \%$.

In the period November 1997 to January 1998, seven state banks no deposits decreased by $10 \%$. On the contrary, third-party funds to the government banks have increased by $9.6 \%$ in November 1997. Withdrawal of funds from foreign banks is also not much different from the government bank. In November 1997, only one bank that declined a third party fund. Meanwhile, in December 1997 to January 1998 there were no third-party withdrawals of less than 10\%. Even otherwise showed an increase of 6.8\% in November 1997.

With these developments, the share of third-party funds owned banks and foreign banks increased respectively by $42.8 \%$ and $7.2 \%$ in December 1997 to be respectively $47.7 \%$ and $9.3 \%$ at the end of January 1998. In contrast, the share of third-party funds and Non forex BUSN BUSN Foreign exchange decreased from respectively $43.2 \%$ and $2.2 \%$ in December 1997 amounted to $36.9 \%$ and $1.5 \%$ in January 1998 (Table 3.4). These developments indicate the presence of the diversion of funds from private banks to state banks and foreign banks.

\begin{tabular}{|c|c|c|c|c|c|}
\hline \multicolumn{6}{|c|}{$\begin{array}{l}\text { Table } 1 \text {. } \\
\text { Shares of funds from third-party banking }\end{array}$} \\
\hline \multirow{2}{*}{ Bank Groups } & Dec. 97 & Dec. 97 & Jan. 98 & Feb. 98 & Mar. 98 \\
\hline & \multicolumn{5}{|c|}{ Share (\%) } \\
\hline Public Banks & & & & & \\
\hline 1. National Bank & 36.0 & 42.8 & 47.7 & 47.0 & 46.6 \\
\hline $\begin{array}{l}\text { 2. National Private Foregin } \\
\text { Exchange Bank }\end{array}$ & 49.7 & 43.2 & 36.9 & 37.1 & 37.6 \\
\hline $\begin{array}{l}\text { 3. National Private Non-Foreign } \\
\text { Exchange Bank }\end{array}$ & 5.5 & 2.2 & 1.5 & 1.9 & 2.3 \\
\hline $\begin{array}{l}\text { 4. Regional Development } \\
\text { Bank (BPD) }\end{array}$ & 2.8 & 2.2 & 2.6 & 1.7 & 1.6 \\
\hline 5. Mixed Banks & 1.7 & 2.7 & 3.0 & 3.0 & 2.8 \\
\hline 6. Foreign Banks & 4.1 & 7.2 & 9.3 & 9.3 & 9.2 \\
\hline $\left.\mathrm{BBR}^{\star}\right)$ & 0.5 & 0.4 & 0.3 & 0.3 & 0.3 \\
\hline
\end{tabular}


In addition to third-party transfer of funds to banks categorized as healthy (flight to quality), there is also a transfer of funds to the currency (currency), as reflected in the increase of currency in January 1998 of $31.8 \%$ (U.S. \$ 9.045 trillion) compared to the month before. The increase was outside the normal pattern of demand for currency, which is based on data two years prior to the crisis, the average currency growth of $9.5 \%$ in just a idea.

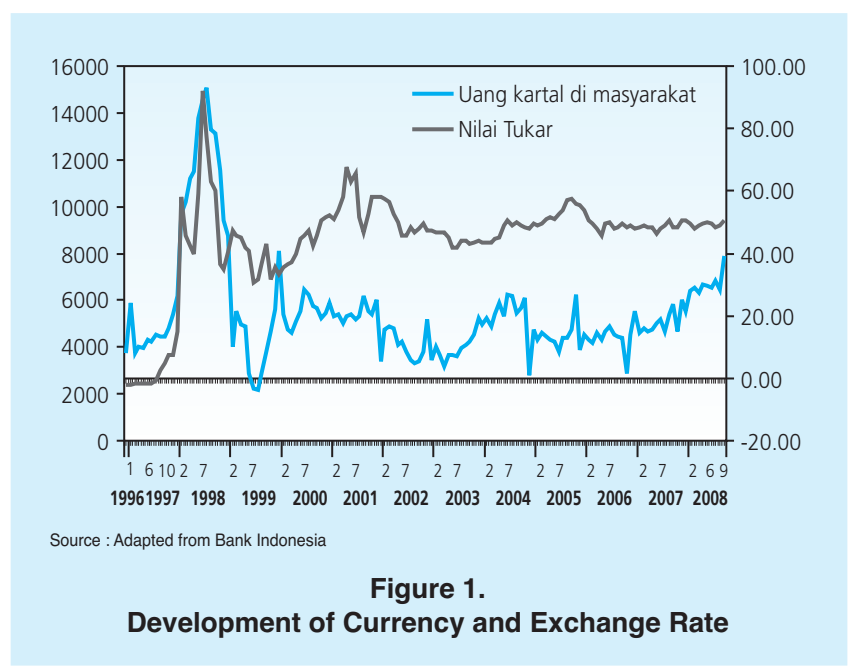

The banking crisis further exacerbated by the depreciation of the rupiah is very large. In January 1997, the rupiah against the U.S. dollar (U.S.) in the position of Rp 2396. The position of the exchange rate continues to decline. In July 1997 the exchange rate was recorded in the position of Rp 2599 per U.S. dollar, and in December 1997 to Rp 4650 per U.S. dollar. In 1998 the position of the exchange rate has decreased dramatically, reaching the position of Rp 10,525 per U.S. dollar in May 1998 and continued to weaken to a peak in June 1998 in the position of Rp 14,900 per U.S. dollar. From the position of the rupiah strengthened to begin in December 1998 in the position of Rp 8025 per U.S. dollar.

Withdrawal of bank funds on a large scale by the customer and the depreciation of the rupiah exchange rate put pressure on bank balance (balance sheet). These conditions resulted in the overall performance of the national banking system worsened. Banking performance degradation occurs in all aspects of bank finance, which includes the capital, asset quality, profitability, and liquidity. Performance capitalization (CAR) declined sharply since the crisis, as reflected in the drop all the bank's CAR of $9.19 \%$ at the end of December 1997 amounted to $-15.68 \%$ at the end of December 1998. Similarly, the performance of asset quality (KAP), which is measured from the ratio of earning assets classified as non-current assets by total earning assets, increased from $4.80 \%$ at the end of 1997 amounted to $42.39 \%$ at the end of 1998, before decreased to $12.74 \%$ at the end of 1999 as a result of the transfer of troubled bank loans to IBRA. 
In line with the worsening of KAP, the performance of profitability, as measured by the ratio of income to average assets (ROA), decreased from $1.37 \%$ in 1997 to $-18.76 \%$ in 1998 and $-6.14 \%$ in 1999 . Losses experienced by almost all the banks due to the high cost of funds incurred bank, with one-month deposit rate reached 70\% in September 1998. While on the other side of KAP increased and decreased the number of loans in line with the economic contraction (13.1\% in 1998) and increased business risk due to social instability, political, and security. In line with the decline in credit, the loan to deposit ratio (LDR) of the banks also fell sharply by $86.42 \%$ at the end of 1997 amounted to $72.37 \%$ at the end of 1998 and only amounted to $26.16 \%$ at end of 1999 .

\section{METHODOLOGY}

Markov Switching Models in this paper uses a latent variable that follows the first derivative of the two-state markov pathways, ie $\left\{s_{t}\right\}_{t=1}^{T} \cdot s_{t}=1$ is a crisis stateand $s_{t}=0$ is a state of calm (tranquil state). Although in this model $\mathrm{s}_{\mathrm{t}}$ not observed directly, the behavior of the dependent variable $\left(\mathrm{y}_{\mathrm{t}}\right)$ is free of $\mathrm{s}_{\mathrm{t}}$ and denoted as follows:

$$
y_{t} \mid s_{t} \stackrel{i i d}{\sim} N\left(\mu_{s_{t}}, \sigma_{s_{t}}^{2}\right)
$$

Dependent variable $\left(\mathrm{y}_{\mathrm{t}}\right)$ is used as an early warning indicator of bank runs is the percentage change in third-party bank funds from 1990-2005. Thus the model of Markov-Switching (MS) uses only univariate models. We choose the percentage change in bank third-party funds, since bank runs by definition is a massive withdrawal of funds to third parties. The signal of a persistence decrease of third-party funds, it is known the occurrence of bank runs on a bank.

In MS the model, the average value (mean) and variance of $\mathrm{y}_{t}$ can be changed according to the regime. The density of the conditional $\mathrm{s}_{\mathrm{t}}$ can be formulated as follows:

$$
f\left(y_{t} \mid s_{t}\right)=\frac{1}{\sqrt{2 \pi \sigma_{s_{t}}}} \exp \frac{\left[-\left(y_{t}-\mu_{s_{t}}\right)^{2}\right]}{2 \sigma_{s_{t}}^{2}} \quad \text { for } \mathrm{s}_{\mathrm{t}}=0,1
$$

Latent variable for regime switching, $\mathrm{s}_{\mathrm{t}^{\prime}}$ is obtained from the transition matrix probability $\mathrm{P}_{\mathrm{t}}$ as the following: 


$$
\begin{aligned}
& \text { Period } t
\end{aligned}
$$

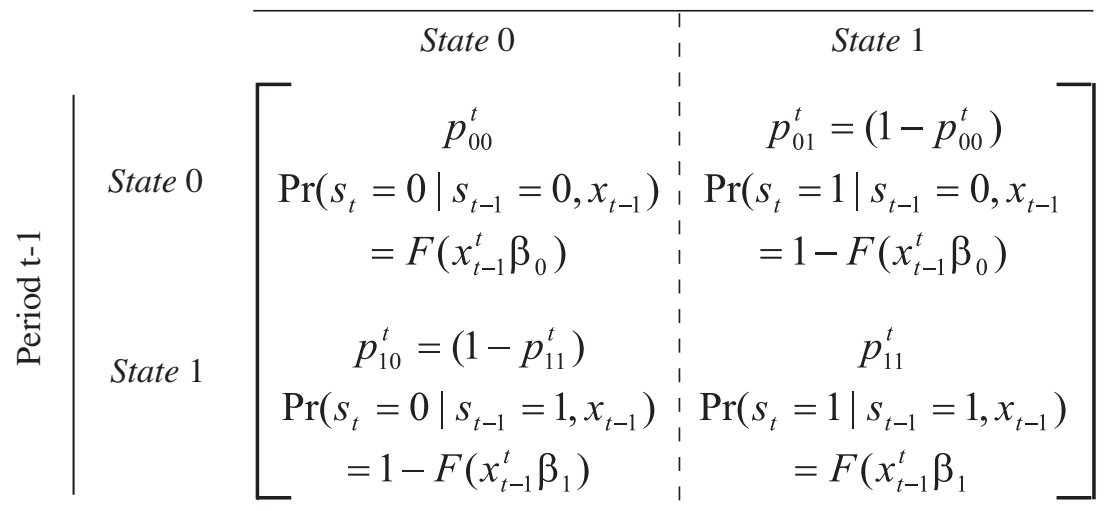

where $\boldsymbol{p}_{i j}^{t}$ is the possibility of displacement of statein period $t-1$ to state in period tand $\mathrm{F}$ is the normal cumulative distribution function cdf component of the vector $k x 1$ and $x_{t-1}$, the early warning indicator that can affect the probability of transition (transition probabilities).

To run this model requires the initial value, i.e. $p_{1}{ }^{1}=\operatorname{Pr}(\mathrm{s}=1)$ which isan unconditional probability to the result in state 1 for period 1 . The treatment of these values depends on whether or not $x_{t}$ is stationary. If $x_{t}$ is stationary then the long-term probability $p_{1}{ }^{1}$ is $s_{1}=1$ and is a function of $\left(\beta_{0}, \beta_{1}\right)$ In the meantime, if $\mathrm{x}_{\mathrm{t}}$ is not stationary then $p_{1}{ }^{1}$ is an additional parameter that must be estimated. In practice, if time series data are long enough, the likelihood function will not be affected whether performed by calculating the functions of $\left(\beta_{0}, \beta_{1}\right)$ separately or by setting its value - it still does not make a difference.

Estimation procedure is used to maximize the likelihood function. The likelihood function is calculated using iterations as shown by Hamilton (1990). By using the information available up to period $t$, we can form $\operatorname{Pr}\left(s_{t}=j \mid \Omega_{t} ; \Theta\right)$, the conditional probability (filtered) from observationi which comes from the regime $j$, where $j=1,2, \ldots N$. N the state, which in this study used $N=2$. Further more, the conditional probabilities are collected in a vector $(N \times 1) \xi_{t \mid t}$.

Predictions can also be done through a conditional probability (forecast) regimejfor period $t+1$ with information until the period $t$, which can be denoted $\operatorname{Pr}\left(s_{t+1}=j \mid \Omega_{t} ; \Theta\right)$, for $\mathrm{j}=1,2, \ldots \mathrm{N}$. Estimation of probabilities is collected in a vector $(N \times 1) \xi_{t+1 \mid t}$. Lastly, $\eta_{t}$ denoted as a vector (Nx1) with components that have as many as $\mathrm{j}$ is a conditional density function of equation (2). Probability has been filtered and calculated for each period $t$ by iteration of the following equations:

$$
\begin{aligned}
& \hat{\xi}_{t \mid t}=\frac{\left(\hat{\xi}_{t \mid t-1} \circ \eta_{t}\right)}{1^{\prime}\left(\hat{\xi}_{t \mid t-1} \circ \eta_{t}\right)} \\
& \hat{\xi}_{t+1 \mid t}=P_{t+1}^{\prime} \hat{\xi}_{t \mid t}
\end{aligned}
$$


where $\mathbf{P}_{t}$ is the matrix size NxN of the transition probabilities of the period $t-1$ until period $t$ as expressed in the equation (4) and 0 is the notation multiplication of each element. Equation (5) calculated by $\operatorname{Pr}\left(s_{t}=j \mid \mathrm{W}_{t} ; \mathrm{Q}\right)$ is the joint distribution ratio $f\left(y_{t}, s_{t}=j \mid \mathrm{W}_{t} ; \mathrm{Q}\right)$ for the marginal distribution $f\left(y_{t}=j \mid \mathrm{W}_{t} ; \mathrm{Q}\right)$. Marginal distribution is obtained by summing the joint distribution of the two states. Equation (5) suggests that the best estimate available for the time of the current state position, we simply multiply the transformation matrix $\mathrm{P}$ of the transition probabilities to obtain estimates of the probability of each state in the next period.

\section{RESULTS AND ANALYSIS}

As outlined in the section 4, to calculate the probability of transition from quiet state (tranquil) to states of bank runs the Markov-Switching model (MS) is used with auto regressive approach, using the estimation process of equation (6) to equation (41). A variable was used to estimate the percentage change in third party funds individual banks (y). To ensure the data is stationary, smoothing of the data will be done by the Kalman filter method. Testing the validity of the MS models as an early indicator of bank runs were performed on each individual bank types by comparing the actual occurrence of bank runs.

\section{a. National Bank (NB)}

Signal the occurrence of bank runs on the model of Markov-Switching (MS) seen from the values of the transition probabilities of a quiet state (no bank runs) to a state where bank runs occur. A probability value greater than 0.5 means the possibility of a bank run is greater than $50 \%$ and a value of 1 means the possibility of bank runs to reach $100 \%$. Conversely, if the value is 0 , then the possibility of bank runs $0 \%$. MS model results to the government banks showed very infrequent signals found in bank bank runs (Table 2). Reflecting the value of the transition probabilities from a quiet state to a bank run state occurs in almost every month just by 0 . Of the 147 months observed at each individual bank there were only 16 months for the incidence of bank runs as indicated by BP1, BP2 for 7 months, 5 months to BP3, BP4 and 4 months to 5 months to BP5, with a probability value in the range 0.7 to 1 . However, the bank run signals were not persistent (continuous), as reflected in the declining value of the transition probability occurrence of bank runs ranging 0.7 to 1 then to 0 in the following months.

Meanwhile, in the banking crisis period 1997-1998, the model MS did not find a signal for bank runs for government banks as reflected in the value of the transition probabilities from a quiet state to a bank run state at 0 for the period. In test results on real events particularly in the period 1997-1998, the models of MS was accurate for detecting bank runs. From the observation period (January 1988-March 2000) of the five state-owned banks, only 6 months $(0.82 \%)$ gives a wrong signal for bank runs (type 2 error $)^{6}$. 


\begin{tabular}{|c|c|c|}
\hline \multicolumn{3}{|r|}{$\begin{array}{c}\text { Table } 2 . \\
\text { Markov-Switching Results }\end{array}$} \\
\hline No & Bank & Months of Bank Runs Signals \\
\hline 1 & NB1 & $\begin{array}{l}\text { Apr, May, Aug \& Nov-88, Jan, Apr, Jul, Aug \& Oct-89, Jan, Apr, Jul \& Aug-90, } \\
\text { Feb \& Mar-91, Sept-94 }\end{array}$ \\
\hline 2 & NB2 & Apr \& Dec-91, Oct Nov 92, Dec-99, Jan \& Feb-00 \\
\hline 3 & NB3 & Mar \& Apr-91, Oct, Nov \& Dec-99 \\
\hline 4 & NB4 & Mar, Apr \& Dec-91, Sept-94 \\
\hline 5 & NB5 & Aug-89, Mar, Apr, May \& Jul-90 \\
\hline
\end{tabular}

\section{b. Private Banks - Foreign Exchange (PBFX)}

Based on the analysis of 26 private banks, foreign exchange (PBFX) using a model of MS suggested that bank runs were visible signals at seven banks (Table 3 ). This was reflected in the value of the transition probabilities from quiet state to bank run state on each of the banks in the range of 0.8 to 1 and the figure is likely persistent in a few months. Based on the study of

\begin{tabular}{|c|c|c|}
\hline \multicolumn{3}{|r|}{$\begin{array}{c}\text { Table } 3 . \\
\text { Markov-Switching Results for Private Bank Foreign Exchange }\end{array}$} \\
\hline No & Bank & Months of Bank Runs \\
\hline 1 & PBFX5 & $\begin{array}{l}\text { Aug-90, Sep-91, Aug, Sep \& Dec97, Jan, Feb \& Mar-98, Aug \& Dec-00, } \\
\text { Nov \& Dec-00, Jan, May, Jul \& Aug-02, Aug-03, Sep-04 }\end{array}$ \\
\hline 2 & PBFX10 & $\begin{array}{l}\text { Aug-90, Jun, Jul, Nov \& Dec-92, Jan-93, Oct \& Nop-97, Jan, Feb \& Mar-98, } \\
\text { Feb, Sep, Oct, Nov \& Dec-99, Feb, Mar, Apr, May, Jun \& Jul-00, Jan, Aug, } \\
\text { Sep \& Oct-01, Aug-02, Aug-03 }\end{array}$ \\
\hline 3 & PBFX19 & $\begin{array}{l}\text { Dec-88, Oct-89, Jan, Feb \& Sep-90, Nov \& Dec-97, Jan, Mar Apr, Jun, Jul \& } \\
\text { Aug-88, Mar, Apr Jun, Jul \& Aug-99, Apr \& May-00, Jul \& Oct-02, Jan, Apr, } \\
\text { Jun \& Aug-03, Dec-04, Jan \& Nov-05 }\end{array}$ \\
\hline 4 & PBFX22 & $\begin{array}{l}\text { Oct-95, Aug \& Sep-98, Mar, Jun \& Jul-99, Sep \& Nov-02, Feb, Mar, Aug, Oct } \\
\text { \& Nov-03, Jan, Apr, May, Nov \& Dec-04 }\end{array}$ \\
\hline 5 & PBFX23 & $\begin{array}{l}\text { Dec-97, Jan, May, Jun, Jul, Sep \& Nov-98, Jan, Feb, Mar, Apr, Jul, Aug, Oct \& } \\
\text { Dec-99, Jan, Feb, Mar \& Apr-00, Nov \& Dec-02,May \& Aug-03, Nov-05 }\end{array}$ \\
\hline 6 & PBFX24 & $\begin{array}{l}\text { Feb, Apr, Jun, Aug \& Oct-91, Sep \& Dec-92, Mar-93, Feb, Mar, Apr, Jun, Jul } \\
\text { \& Aug-98, Jul-00, Aug \& Sep-02, Jan-Oct \& Nov-05 }\end{array}$ \\
\hline 7 & PBFX26 & $\begin{array}{l}\text { Sep-88, Oct \& Nov-92, Jan, Apr \& Jun93, Jul-96, Jun \& Jul-98, Mar, Jul \& } \\
\text { Aug-99, Jan, Jul, Aug, Oct, Nov \& Dec-03, Feb-05 }\end{array}$ \\
\hline
\end{tabular}

6 Frozen Bank operations (BBO) is a bank temporarily suspended its operations. Signal size is correct for banks experiencing bank runs and banks facing liquidity problems due to the withdrawal of clients. Value of $0.82 \%$ of the total signal obtained one month divided by the total in 5 bank, which is 6 divided by 735 . 
actual events especially during the banking crisis of 1997-1998, the seven banks suffered bank runs. In the period before and after 1997-1998, the seven banks also often showed signs of bank runs with the transition probability value for bank runs in the range of 0.7 to 1 .

Meanwhile, the MS also showed that there were 12 banks that never showed signs of bank runs, as reflected in the value of the transition probability of 0 . PBFX signaled a bank run only a few times, but the signal was not persistent for a few months. From a total of 216 months (January 1988 - December 2005) and 26 banks, found only 57 months of total (1.01\%) gave a wrong signal.

\section{c. Private Banks- Non-Foreign Exchange (PBNFX)}

Based on the observations of 31 private non-bank foreign exchange (PBFX), the MS signaled the occurrence of bank runs in 20 banks, with aprobabilityvalue of the occurrencesfor bank runs ranging from 0.8 to 1 (Table 4). Based on the analysis of the actual events of 1997-1998,

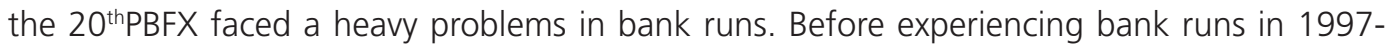
1998, all the banks were showing signs for bank runs that tended to be persistent, as seen from the value of the transition probability of bank runs in the range of 0.9 to 1 . The same signal continued until 2000, as the frequency ofbank runs signals tended to decrease, with transition probabilities in the range of 0.8 to 1 .

The $11^{\text {th }}$ PBNFXalso showed bank runs signals, but not as much as the $20^{\text {th }}$ PBNFXabove. In addition, the value of the transition probability of 11 eleven banks were also lower, with values in the range of 0.6 to 1. In the banking crisis of 1997-1998, the eleventh bank does not face problems of bank runs. Based on the comparison with the actual events, the MS results gives the wrong signal for 94 months (1.4\%). Thus, MS is still shows relatively accurate results when used to detect the occurrence of bank runs.

\begin{tabular}{|c|c|c|}
\hline \multicolumn{3}{|r|}{$\begin{array}{l}\text { Table } 4 . \\
\text { Markov-Switching Results for Private Bank Non-Foreign Exchange }\end{array}$} \\
\hline No & Bank & Months of Bank Runs \\
\hline 1 & PBNFX2 & Dec-88, Jul, Oct \& Dec-93, Feb, Apr, Jul \& Sept-95, Nov-Dec-97, Jan-98 \\
\hline 2 & PBNFX3 & $\begin{array}{l}\text { Dec-88, De93, Nov \& Dec-94, Feb, Mar, Apr, Jun \& Sept-95, Feb \& Mar99, } \\
\text { Oct \& Nov-01, Dec-02, Dec-03 Dec-04, Jan, Jun \& Jul-05 }\end{array}$ \\
\hline 3 & PBNFX6 & $\begin{array}{l}\text { Mar, Nov \& Dec-88, Dec-93, Jan, Sept, Oct, Nov \& Dec-94, Feb, Mar, Apr, } \\
\text { Jun, Aug \& Sept-95, Nov \& Dec-97, Mar-99, Nov-01 }\end{array}$ \\
\hline 4 & PBNFX7 & $\begin{array}{l}\text { Mar, Jun, Sept \& Dec-88, Oct-89, Nov \& Dec-93, Dec-94, Apr, Jul, Aug } \\
\text { \& Sept-95, Oct \& Nov-97, Jan-98, Feb, Mar, May, Jun, Jul, Aug \& Nov-99, } \\
\text { Oct, Nov-01, Jan-03, Jan-04, Jan-05 }\end{array}$ \\
\hline 5 & PBNFX9 & $\begin{array}{l}\text { Mar, Jul, Nov \& Dec-88, Jan-90, Apr-92, Jul-93, Dec94, Apr \& Sept- } \\
\text { 95, Nov \& Dec-97, Feb-99 }\end{array}$ \\
\hline 6 & PBNFX10 & $\begin{array}{l}\text { Mar, Jun \& Nov-88, Jan, Apr, Jul, Oct \& Dec-91, Feb, Apr, Jul, Aug, Oct \& } \\
\text { Nov-92, Jan, Feb, Apr, May, Jul \& Sept-93, Mar, Apr, Sept, Nov \& Dec-94, } \\
\text { Feb, Mar, Apr, Aug \& sept-95, Dec-97, Jul-98, Feb, Mar Jul \& Oct-99 }\end{array}$ \\
\hline
\end{tabular}




\begin{tabular}{|c|c|c|}
\hline No & Bank & Months of Bank Runs \\
\hline 7 & PBNFX11 & $\begin{array}{l}\text { Aug, Sept \& Oct-88, Jan, Aug \& nov-91, Apr, May, Jun, Jul, Aug, Sept \& Dec- } \\
\text { 92, Feb, Apr, May, Jul, Nov \& Dec-93, May, Jul, Sept, Oct \& Dec-94, Feb, } \\
\text { Apr, Jun \& Sept-95, Feb, Apr, May Jun, Jul, Nov \& Dec-96, Jul, Sept \& Nov- } \\
\text { 97, May, Jun, Aug, Sep, Oct \& Dec-99, Jun-00 }\end{array}$ \\
\hline 8 & PBNFX14 & $\begin{array}{l}\text { Dec-91, Dec-93, Feb, Apr, Nov \& Dec-94, Mar, Apr, Jul \& Sept-95, Jan, } \\
\text { Aug, Sept, Nov \& Dec-97, Apr, May, Jul Oct-98, Mar, Apr \& May-99 }\end{array}$ \\
\hline 9 & PBNFX16 & $\begin{array}{l}\text { May \& Jul-88, Jul, Nov \& Dec-93, Jul, Sept \& Oct-97, Dec-98, Jan, Mar, } \\
\text { Apr \& May-99 }\end{array}$ \\
\hline 10 & PBNFX17 & $\begin{array}{l}\text { May-88, Nov-92, Feb, Jul, Sept \& Dec-93, Mar, Apr, Jun \& Dec94, Feb, } \\
\text { Mar, Apr, Jun \& Sept-95, Aug, Sept \& Oct-97, May, Aug, Sept, Oct \& Dec- } \\
\text { 98, Jan, Apr, May, Aug \& Oct-99, Jan, Feb, Mar, May-00 }\end{array}$ \\
\hline 11 & PBNFX18 & $\begin{array}{l}\text { Jun, Jul, Oct \& Nov-88, Jan-92, Jun, Jul, Sept, Nov \& Dec-93, Nov \& Dec-94, } \\
\text { Mar, Apr \& Sept-95, Jan, Mar, Jun, Aug, Oct \& Nov-98, Jan, Feb \& Mar-99 }\end{array}$ \\
\hline 12 & PBNFX19 & $\begin{array}{l}\text { May, Jul, Sept \& Nop-88, Jan, Apr \& May-92, Jan, Feb, Jul, Sep, Oct \& Dec- } \\
\text { 93, Jan, Feb, Mar, Apr, Jul, Aug, Sept \& Dec-94, Feb, Jun, Jul \& Sept-95, Mar, } \\
\text { Apr, Jul, Sept Nov-96, Jan, Feb, Apr, Jul, Aug, Sept, Oct \& Nov-97, Mar, Apr, } \\
\text { Jun, Sept, Oct \& Nov-98, Jan, Apr Sept \& Oct-99, Feb \& Jul-00 }\end{array}$ \\
\hline 13 & PBNFX20 & $\begin{array}{l}\text { Jul \& Aug-88, Jan, Apr, Jul \& Aug92, Feb, Apr, Jul, Aug \& Dec-93, Mar, Apr, } \\
\text { May, Jul, Sept \& Dec-94, Mar, Apr \& Sept-95, Mar \& Nop-96, Jan, May, Jun, } \\
\text { Jul \& Oct97, Jan, Jun, Jul, Aug, Sept, Oct \& Nov-98, Jan, Feb, Mar, Jul, Sept } \\
\text { \& Oct-99 }\end{array}$ \\
\hline 14 & PBNFX21 & $\begin{array}{l}\text { Mar, May, Jul, Oct \& Nov-88, Oct-92, Mar \& Dec-93, Nov \& Dec94, Apr, Jul \& } \\
\text { Sept-95, Dec-97, Jan-98, Feb-99, Jul-00 }\end{array}$ \\
\hline 15 & PBNFX22 & $\begin{array}{l}\text { Mar \& Jul-88, Jan, Jul, Sept \& Dec-93, Mar, May, Jul, Aug \& Dec-94, Mar, Apr, } \\
\text { Jun, Jul, Aug, Sept, Nov \& Dec-95, Mar, May, Jun, Jul, Oct \& Dec-96, May, Oct } \\
\& \text { Nov-97, Mar, May, Aug, Nov \& Dec-98, Jan, Mar, May, Jun, Jul, Sept \& Dec99, } \\
\text { Jan, Feb \& Mar-00 }\end{array}$ \\
\hline 16 & PBNFX25 & $\begin{array}{l}\text { Mar, May \& Jun-88, Oct \& Dec-93, Oct \& Dec-94, Jan, Apr, Jul \& Sept-95, Oct } \\
\& \text { Nov-97, Jan, May, Jul, Aug, Sep, Oct \& Dec-98, Apr \& Jul99 }\end{array}$ \\
\hline 17 & PBNFX26 & $\begin{array}{l}\text { Sep \& Nop88, Jan, Jul \& Dec-93, Mar, Aug, Oct \& Dec-94, Jan, Apr, Sept \& } \\
\text { Dec-95, Mar-96, Feb, Oct \& Nov-97, Jan, May, Jun \& Aug-98, Jan, Mar, Jul } \\
\& \text { Dec-99, Feb, Mar, May \& Jun-00 }\end{array}$ \\
\hline 18 & PBNFX27 & $\begin{array}{l}\text { Jul \& Sept-98, Jan \& Jul-93, Apr \& Dec-94, Apr, Sept \& Nov-95, Jan, Feb, Apr, } \\
\text { May, Jun, Jul, Sept, Oct, Nov \& Dec-96, Sept \& Dec-97, Jan, May, Jul, Sept \& } \\
\text { Dec-98, Feb, Mar, Apr, May, Aug, Nov \& Dec99, Jul-00 }\end{array}$ \\
\hline 19 & PBNFX29: & $\begin{array}{l}\text { May, Jun, Jul \& Nov-88, Mar, Jun, Aug, Nov \& Dec-94, Feb, Apr, Jul, Aug \& } \\
\text { Sept-95, Aug, Sept, Oct \& Nov-97, Apr, May, Aug, Sept Nov-98, Feb, Mar, } \\
\text { May, Jun, Jul, Sept \& Oct-99, Mar-00 }\end{array}$ \\
\hline 20 & PBNFX31: & $\begin{array}{l}\text { Apr, Jul \& Dec-94, Mar, Apr, Sept, Nov \& Dec-95, Jan, Apr, May, Aug, Oct \& } \\
\text { Nov-96, Feb, Apr, Aug, Nov \& Dec-97, Jun, Aug, Oct Dec-98, Jan, Apr, May \& } \\
\text { Aug-99, Feb, Mar \& Jun-00 }\end{array}$ \\
\hline
\end{tabular}

\section{d. Foreign Banks (FB)}

Markov-Switching(MS) results showed that there were 4 of 6 foreign banks observed frequently showing signs of bank runs with a transition probability value from quiet state to bank runs state in the range of 0.6 to 1 (Table 5). In the period of the banking crisis in 1997/1998, the MS model showed the four banks experiencing bank runs. Meanwhile, two other banks never gave signals for bank runs, which was reflected by the transition probability values for bank runs at 0 . Actual events showed that the two banks were never subjected to bank runs. 
On a whole, for the period January 1988 to December 2005, the observed data for the MS gave an incorrect signal totaling 27 months or $2.08 \%$ of the total of 6 banks over 216 months observed. Thus, the signal from the MS model in foreign banks is sufficiently accurate to monitor the possibility of a bank run on one bank.

\begin{tabular}{|c|c|c|}
\hline \multicolumn{3}{|r|}{$\begin{array}{l}\text { Table } 5 . \\
\text { Markov-Switching Results for Foreign Banks }\end{array}$} \\
\hline No & Bank & Months of Bank Runs \\
\hline 1 & FB1 & $\begin{array}{l}\text { Jan, Apr, May, Sept \& Dec-90, Jan, Feb, Mar, Jun \& Jul-91, Jul \& Sept-97,Jun, } \\
\text { Jul, Aug \& Sept-98, Jan, Aug, Sept \& Oct-02, Jan, Feb \& May 03, Jan, Mar, Apr, } \\
\text { Aug \& Nop-04, Feb, Jun, Jul \& Aug-05 }\end{array}$ \\
\hline 2 & FB2 & $\begin{array}{l}\text { Feb, May, Sep, Oct \& Nop-89, Jan, Mar, Apr, Jun, Jul, Aug \& Oct-90, Jan, Apr, } \\
\text { Aug, Sept \& Nop-93, Jan, Apr, Aug, Sept \& Nop-93, Feb, Mar, Apr, Jul, Oct \& Dec- } \\
\text { 95, Jan Feb, Mar, Apr \& Aug 96, Jan, Mar, Apr, Jun, Jul, Aug \& Oct-97, Feb, Jul, } \\
\text { Aug, Sept \& Nop-98, Feb, May, Jun \& Aug-00, Jan, Feb, Mar, Jun, Jul, Aug, Oct \& } \\
\text { Dec-01, Jan, Feb, Mar, Apr, Jul, Aug, Oct-02, Apr, May \& Jul-03, Jan, Feb, Mar, } \\
\text { Apr, Jun, Sep \& Oct-04, Jan, Feb, Mar, Apr \& Aug-05 }\end{array}$ \\
\hline 3 & FB3 & $\begin{array}{l}\text { Apr, Jul \& Dec-93, Feb, Mar, May, Jun, Sept, Oct \& Nov-94, Jan, Mar, Apr, Apr, } \\
\text { Jul, Aug \& Oct-95, Feb, Mar, May, Jun \& Aug-96, Feb, Aug, Sept, Oct-97, Apr, } \\
\text { Jun, Jul, Aug, Sept, Oct \& Dec-98, Jun-99, Feb-02, Jul, Sept \& Oct-04, Jan, Jun } \\
\text { \& Jul-05 }\end{array}$ \\
\hline 4 & FB4 & $\begin{array}{l}\text { Jun, Aug, Oct \& Dec-89, Jan, Apr, May, Jun \& Aug-90, May, Aug, Oct \& Dec-93, } \\
\text { Feb \& Mar-94, Jul, Oct \& Dec-95, Feb \& Mar-96, Jun \& Oct-97, Apr, Jun, Jul \& } \\
\text { Aug-98, May, Jun \& Aug-05 }\end{array}$ \\
\hline
\end{tabular}

\section{e. Mixed Banks (MB)}

MS results of the observed signalsfor a mix of nine banks (MB) indicated the occurrence of banking crisis bank runs in the period 1997-1998, with a transition probability value of 1 , which means $100 \%$ like lihood of bank runs. These results are consistent with the actual events, where the 9 banks suffered the occurrence of bank runs. Meanwhile, judging from the frequent occurrence of bank run signals, there were 4 banks that were experiencing bank runs (Table 6) with a probability occurrence value of ranging from 0.7 to 1 .

The comparison of results that actually produced the wrong signal was as much as 18 months or $0.93 \%$ of the total banks and months observed. MS results from the mix of banks also indicated that the model is accurate enough to use MS as an early warning indicator for the occurrence of bank runs on each individual bank. 


\begin{tabular}{|c|c|c|}
\hline \multicolumn{3}{|r|}{$\begin{array}{c}\text { Table } 6 . \\
\text { Markov-Switching Results for Mixed Banks }\end{array}$} \\
\hline No & Bank & Months of Bank Runs \\
\hline 1 & MB2 & $\begin{array}{l}\text { Apr, Aug, Oct, Nov \& Dec-90, Feb, Mar, Apr, May, Aug, Sept \& Nov-91, Jan, Mar, } \\
\text { Jul, Aug \& Oct-92, Jan, Feb, May, Jul, Aug \& Oct-93, Jan, Mar, Apr, Jun, Jul, Aug } \\
\text { \& Oct-94, Jan, Feb, Mar-95, Sep, Oct, Nov \& Dec-96, Feb, Mar, Apr, May, Aug \& } \\
\text { Nov-97, Feb, Mar, Apr, Jul, Oct, Nov \& Dec-98, Jan, Feb, Apr, May \& Aug99, } \\
\text { Sept-04, Jan, Feb, May-05 }\end{array}$ \\
\hline 2 & MB5 & $\begin{array}{l}\text { May, Aug \& Nop90, Mar, Apr, May, Jul \& Oct-91, Jan, Apr, May, Jun, Jul \& Aug- } \\
\text { 04, Aug, Sept \& Nov-97, Feb, Apr, Jun, Jul \& Sept-98 }\end{array}$ \\
\hline 3 & MB6 & $\begin{array}{l}\text { Dec-89, Jan, Apr, May, Jul, Aug, Oct, Nov Dec-90, Jan, Apr, May, Jun, Nov \& Dec- } \\
\text { 91, Jan, Apr, Jun, Aug \& Oct-92, Jan, Apr, May, Jun, Jul, Oct \& Dec-93, Mar, } \\
\text { Apr, Jul, Aug, Oct, Nov \& Dec-94, Feb, Mar, Apr, Jun, Jul, Sept, Oct \& Dec-95, Jan, } \\
\text { Mar, Apr, jul, Aug \& Dec-96, Feb, Jul, Sept \& Oct97, Jan, Mar, Apr, May, Jul, Sept, } \\
\text { Oct, Nov \& Dec-97, Feb, Mar, Apr, Jun, Jul \& Dec-99, Feb, Mar, Jun, Jul, Aug \& } \\
\text { Dec-00, Jan-01 }\end{array}$ \\
\hline 4 & MB7 & $\begin{array}{l}\text { Jul \& Oct-90, Jan, Apr, May, Jun, Aug \& Nov-91, Jan, Sept \& Oct-92, Jan, Feb, } \\
\text { Mar, Apr, May, Jun, Jul, Aug, Sept \& Oct-93, Mar, Apr \& May-94, Apr, Jun, Aug, } \\
\text { Oct, Nov \& Dec-95, Jan, Mar, May, Jun, Sept, Oct \& Nov-96, Jan, Mar, May, Jun, } \\
\text { Sep, Oct \& Nov-97, Apr, Jun, Jul, Oct \& Nov-98,Mar, Jun, Aug-99, Mar, May, Jul } \\
\text { \& Aug-03, Jan, Mar, Apr \& Dec-04, Apr, Jun \& Jul-05 }\end{array}$ \\
\hline
\end{tabular}

\section{f. Banks with Frozen Business Activity (BFBA)}

Of eight frozen bank business models analyzed with MS, only two did not show signs of banking crisis bank runs in the period 1997-1998, while five other banks showed signs bank runs (Table 7), with transition probabilities values for bank runs occurring in the range of 0.9 to 1. Bank run signals often occured in BFBA 2 and 3, with the transition probabilities value for the bank run in the range of 0.9 to 1 . This condition is consistent with the actual events in which bank runs occurred in the period.

Table 7.

Markov-Switching Results for Banks with Frozen Business Activity

\begin{tabular}{|c|c|c|}
\hline No & Bank & Months of Bank Runs \\
\hline 1 & BFBA1 & Aug -89 \\
\hline 2 & BFBA2 & $\begin{array}{l}\text { Aug \& Oct-89, Jan, Jul, Aug \& Nop-90, Jan, Feb, Apr, Jul, Aug \& Oct-91, } \\
\text { Dec-92, Jan, Jul \& Aug-93, Jan-94, Oct, Nov \& Dec-98 }\end{array}$ \\
\hline 3 & BFBA3 & Mar \& Nop-88, Jul \& Aug-90, Jul, Aug \& Dec-91, Oct, Nov \& Dec-92, Nov 98 \\
\hline 4 & BFBA4 & Nov-88, Jul \& Aug-90, Nov \& Dec-92, Dec-93, Dec-98 \\
\hline 5 & BFBA5 & Aug-89, Sep-92, Dec-93, Sep \& Oct-94, Feb, Apr \& Jun-96 \\
\hline 6 & BFBA6 & Oct, Nov \& Dec-88, Jan \& Oct-89, Dec-98 \\
\hline 7 & BFBA7 & Mar, May, Jun, Aug, Sep, Oct, Nov \& Dec-98 \\
\hline 8 & BFBA8 & Apr, May, Sep, Oct, Nov \& Dec-98 \\
\hline
\end{tabular}


Comparison of actual events based on the full sample, showed there were 12 months or $0.69 \%$ incidence of total observations with the wrong signal for the bank run scene. The error signal occured in four banks. By looking at the small difference in the error between the actual results with the incidence of MS, the MS model can be used as an indicator to detect bank runs in troubled banks and individual indicator for the supervision of other banks.

\section{g. Bankswith Frozen Operations (BFO)}

MS results revealed that of the seven banks withfrozen operations (BFO), six banks showed a strong signal for the occurrence of banking crisis bank runs in the period 1997-1998, as reflected in the transition probability value of 1 for bank runs. The $6^{\text {th }} \mathrm{BBO}$ also often signaled bank runs before the crisis (Table 8). One other bank (BFO6) had only signaled the occurrence of bank runs in 1993.

Test results on real events indicate that the MS is able to explain the phenomenon of bank runs on the frozen banks operating in Indonesia for the period 1997-1998. From the overall observation results, only 19 wrong signals occurred or $1.26 \%$ of the total observations.

\begin{tabular}{c|l|l}
\multicolumn{2}{c}{ Markov-Switching Results for Banks with Frozen } \\
No & Bank & \multicolumn{1}{c}{$\begin{array}{c}\text { Table } 8 \\
\text { Months of Bank Runs }\end{array}$} \\
\hline 1 & BFO1 & Aug, Oct \& Nop-88, Jul \& Aug-89, Dec-97, Jan, Apr, May \& Jun-98 \\
\hline 2 & BFO2 & Aug \& Nop-89, Feb-93, Nov \& Dec97, Jan, Feb, Mar, Apr, May \& Jun-98 \\
\hline 3 & BFO3 & Aug \& Nov-88, Aug \& Dec-89, May \& Aug 90, Sep, Oct \& Dec-97 \\
\hline 4 & BFO4 & Aug-90, Jan, Feb \& Apr-91, Jun-92, Dec-94, Dec-97, Jan-98 \\
\hline 5 & BFO5 & Dec-92, Aug, Sep, Oct \& Dec-97, Feb, Mar \& Jun-92, Aug, Sep, Oct \& Dec-97, Jan-98 \\
\hline 6 & BFO6 & Feb, Mar \& Jun-93 \\
\hline 7 & BFO7 & $\begin{array}{l}\text { Apr, Sept, Oct \& Nov-92, Jan, Apr, Oct \& Nov-93, Jan, Feb, May, Aug \& Nov-94, } \\
\text { Feb, Sep \& Dec-95, Feb-96, Jan, Apr, Aug Sept, Oct \& Dec-97, Jan-98 }\end{array}$
\end{tabular}

\section{CONCLUSON}

$M$ arkov-Switching model results (MS) showed that MS models produce results that are robust as early warning indicators of bank runs. Reflecting the results of tests on real events in 102 banks that showed the MS only gives a wrong signal in the range of $0.69 \%$ to $2.08 \%$.

The results of early indicators for bank runs with MS models indicate that banks are experiencing bank runs or banks are in troublewhen the MS produces a persistent signal for bank runs. Monthly scenarios can be developed to derive a daily model to detect the possibility of bank runs. In connection with this, it is suggested that the MS model be used to detect bank 
runs onindividual bank supervision cycles based on risk-based supervision in Indonesia. Research on early warning systems using the MS in the supervision cycle is parallel to the assessment of the risk profile of each individual bank, so the information on the early warning system can be optimized together with other risk assessment of banks in preventing bank runs or other problems that can harm the survival of a bank. 


\section{REFERENCES}

Bank Indonesia, 1997 - 2007, Bank Indonesia Annual Report.

2008, "Indonesian Financial System: 10 years after crisis." DPNP Bank Indonesia working paper.

Beck, Thorsten; Demirguc-Kunt, Asli dan Levine, Ross. "Bank Concentration and Crises." NBER

Working Paper Series, WP No. 9921, Agustus 2003.

Bryant, John. "Bank Collapse and Depression" Journal of Money, Credit and Banking, Vol. 13, No. 4 (Nov., 1981), pp. 454-464.

Calomiris, Charles W. "Bank Failures in Theory and History: The Great Depression and Other

'Contagious' Events." NBER Working Paper Series, No. WP 13597, November 2007.

Caprio, Gerrar, James A. Hanson dan Robert E. Litan. Financial Crises: Lessons from the Past,

Preparation for the Future. Brookings Institution Press, Washington, D.C. 2005.

Catalan, Mario. "Endogenous Bank Runs." UCLA, Oktober 2000.

Demirguc-Kunt, Asli dan Detragiache, Enrica, 1999, "Monitoring Banking Sector Fragility: A

Multivariate Logit Approach." IMF Working Paper, No. WP/99/147, Oktober. , 2005, "Cross-Country Empirical Studies of Systemic Bank Distress: A Survey." Maret.

Diamond, Douglas W. "Debt Maturity Structure and Liquidity Risk." The Quaterly Journal of Economics, August 1991, 106(3), pp. 709-737. , dan Philip H. Dybvig, "Bank Runs, Deposit Insurance, and Liquidity." Journal of Political

Economy, June 1983, 91(3), pp. 401-419.

dan Raghuram G Rajan. "Liquidity Shortages and Banking Crises." NBER Working

Paper Series, WP No. 10071, Oktober 2003.

Eichengreen, Barry dan Arteta C., 2000, "Banking Crises in Emerging Markets: Presumptions

and Evidence". Centre for International Development and Economics Research Working Paper, C00-115, August.

Freixas, Xavier dan Jean-Charles Rochet. "Microeconomics of Banking". The MIT Press, 2002.

Freixas, Xavier, Bruno M. Parigi, dan Jean-Charles Rochet. "Systemic Risk, Interbank Relations, and Liquidity Provision by the Central Bank" Journal of Money, Credit and Banking, Vol. 32, No. 3, Part 2: What Should Central Banks Do? (Aug., 2000), pp. 611-638.

Frydl, Edward J. "The Length and Cost of Banking Crises." IMF Working Paper, No. WP/99/30, March 1999.

Garcia-Herrero, Alicia. "Banking Crises in Latin America in the 1990s: Lessons from Argentina,

Paraguay, and Venezuela." IMF Working Paper, No. WP/97/140, October 1997.

Ghysels, Eric, Robert E. McCulloch, and Ruey S. Tsay, "Bayesian Inference for Periodic RegimeSwitching Models", Journal of Applied Econometrics, Vol. 13, No. 2 (Mar. - Apr., 1998), 129-143. 
Goldstein, Morris, dan Philip Turner.

"Banking Crises in Emerging Economies: Origins and Policy Options" Bank for International Settlements Economic Papers, No. 46 - October 1996

Goldstein, Morris, Graciela L. Kaminsky, and Carmen M. Reinhart. Assessing Financial Vulnerability

: An Early Warning System for Emerging Markets. Institute for International Economics, Washington, DC. June 2000.

Gonzalez-Hermosillo, Brenda, 1999, "Determinants of Ex-Ante Banking System Distress: A Macro-Micro Empirical Exploration of Some Recent Episodes." IMF Working Paper, No. WP/ 99/33, March.

Gorton, G. "Banking Panics and Business Cycles", Oxford Economic Papers, 40, pp. 751-781, 1988.

Hamilton, James D. "A New Approach to the Economic Analysis of Nonstationary Time Series and the Business Cycle". Econometrica, Vol. 57, No. 2 (Mar., 1989), 357-384. 1990, "Analysis of Time Series Subject to Changes in Regime". Journal of Econometrics 45, hal 39-70. Time Series Analysis. Princeton University Press, Princeton, New Jersey, 1994. dan R. Susmel. "Autoregressive Conditional Heteroscedasticity and Changes in Regime,"Journal of Econometrics (64), 1994, pp.307-333.

Hanson, James A. "Postcrisis Challenges and Risks in East Asia and Latin America: Where They Go from Here?", dalam Financial Crises: Lessons form the Past, Preparation for the Future, editors Gerrard Caprio, James A. Hanson, dan Robert E. Litan, 2005.

Hardy, Daniel C. And Ceyla Pazarba_ilu. "Leading Indicators of Banking Crises: Was Asia Different?". IMF Working Paper, WP/98/91, 1998.

. "Determinants and Leading Indicators of Banking Crises: Further Evidence." IMF Staff Papers, Vol. 46, 3 (September/Desember 1999), pp. 247-258.

Ho, Thomas dan Saunders, Anthony. "A Catastrophe Model of Bank Failure." The Journal of Finance, Vol. 35, Issue 5 (Desember 1980), pp. 1189-1207.

Hoelscher, David S. And Marc Quintyn. "Managing Systemic Banking Crises", IMF Occasional Paper No. 224, International Monetary Fund, Washington DC, 2003.

Honohan, Patrick. "Banking System Failures in Developing and Transition Countries: Diagnosis and Prediction". BIS Working Papers, No. 39. dan Luc Laeven. Sistemic Financial Crises: Containment and Resolution. Cambridge University Press, 2005.

Kaminsky, Graciela L.,1999, "Currency and Banking Crises: The Early Warnings of Distress." IMF Working Paper, No. WP/99/178, Desember. and Carmen M. Reinhart, 1998, "Financial Crises in Asia and Latin America: Then and Now" The American Economic Review, Vol. 88, No. 2, Papers and Proceedings of the Hundred and Tenth Annual Meeting of the American Economic Association (May), pp. 444-448. 
dan Reinhart, Carmen M., 1999, "The Twin Crises: The Causes of Banking and BalanceOf-Payments Problems." The American Economic Review, Vol. 89, No. 3 (Juni), pp. 473 500.

Kaufman, George G., 1988, "Bank Runs: Causes, Benefits and Costs." Cato Journal 2, no. 3 (Winter): 559-88.

Kindleberger, C. P. Manias, 1978, Panics and Crashes. Basic Books, New York.

Krolzig, Hans-Martin. Markov-Switching Vector Autoregressions: Modelling, Statistical Inference, and Application to Business Cycle Analysis. Springer, 1997.

Latter, Tony. "The Causes and Management of Banking Crises." Handbooks in Central Banking, No. 12, Bank of England, July 1997.

Lindgren, Carl-Johan, Garcia, Gillian, Garcia dan Saal, Matthew, 1996, I."Bank Soundness and Macroeconomic Policy." IMF.

Meyer, Paul A. dan Pifer, Howard W. "Prediction of Bank Failures." The Journal of Finance, Vol. 25, 4 (September 1970), hal. 853-868.

Minsky, Hyman.

"A Theory of System Fragility", dalam Edward Altman dan Arnold Sametz (ed.), Financial Crises: Institutions and Markets in a Fragile Financial Environment, New York: Wiley-Interscience, 1977.

Mishkin, Frederic S. "Understanding Financial Crises: A Developing Country Perspective." NBER Working Paper Series, No. WP 5600, Mei 1996.

The Economics of Money, Banking, and Financial Markets. Sixth Edition, 2001, AddisonWesley.

Montes-Negret, Fernando dan Muller, Thomas. "Banking System Crises and Recovery in the Transition Economies of Europe and Central Asia: An Overview." in Caprio, Gerard; Hanson, James A.; dan Litan, Robert A. Financial Crises: Lessons from the Past, Preparation for the Future, 2005.

Nagayasu, Jun. "Currency Crisis and Contagion: Evidence from Exchange Rates and Sectoral Stock Indices of the Philippines and Thailand" IMF Working Paper, WP/00/39.

Norden, Simon Van, "Regime Switching as a Test for Exchange Rate Bubbles", Journal of Applied Econometrics, Vol. 11, No. 3 (May - Jun., 1996), 219-251.

Pangestu, Mari dan Habir, Manggi.

"The Boom, Bust, and Restructuring of Indonesian Banks." IMF Working Paper, No. WP/02/66, April 2002.

Peck, James, and Karl Shell.

"Bank Portfolio Restrictions and Equilibrium Bank Runs" Journal of Economic Literature, July 29,1999.

. "Equilibrium Bank Runs" Journal of Political Economy, 2003, vol. 111, No. 1. The University of Chicago. 
Rigobon, Roberto. "On the Measurement of the International Propagation of Shocks: is the Transmission Stable?" Journal of International Economics. 1 October 2002. Elsevier B.V. Summers, Lawrence H. "International Financial Crises: Causes, Prevention, and Cures" The American Economic Review, Vol. 90, No.2, Papers and Proceedings of the One Hundred Twelfth Annual Meeting of the American Economic Association (May, 2000), pp. 1-16. Sundararajan, V. And Tomas J.T. Balino (Edited). Banking Crises: Cases and Issues. International Monetary Fund, 1998.

Warjiyo, Perry, 2001, "Bank Failure Management: The Case of Indonesia" APEC Policy Dialogue on Bank Failure Management Paper, Mexico, June 7-8. 


\section{APPENDIX 1}

This attachment describes the process of howthe estimated transition probabilities value are used as early warning indicators (EWI) of bank runs in this paper. In principle, the model estimates Markov-Switching (MS) using autoregressive models developed by Hamilton (1990). MS model estimation process is described as follows. As mentioned before the variable is used as an early warning indicator is the monthly percentage change in third-party funds $\left(\mathrm{y}_{\mathrm{t}}\right)_{\text {. It }}$ is assumed $\mathrm{y}_{\mathrm{t}}$ follows the autoreggresive model $(3)^{7}$ with parameters that change from a quiet state dengan (nobank runs) to a state of bank runs. For example, the auto reggresive model is

$$
y_{t}=\alpha_{s_{t}}+\phi_{1, s_{t}} y_{t-1}+\phi_{2, s_{t}} y_{t-2}+\phi_{3, s_{t}} y_{t-3}+\varepsilon_{t}
$$

With. $\varepsilon_{t} \sim N\left(0, \sigma_{s_{t}}^{2}\right)$

This equation can be written in the form

$$
y_{t}=x_{t}^{\prime} \beta_{s_{t}}+\varepsilon_{t}
$$

where the parameters used in this equation are

$$
\begin{aligned}
& x_{t} \equiv\left(1, y_{t-1}, y_{t-2}, y_{t-3}\right)^{\prime} \\
& \beta_{s_{t}} \equiv\left(\alpha_{s_{t}}, \phi_{1, s_{t}}, \phi_{2, s_{t}}, \phi_{3, s_{t}}\right)^{\prime}
\end{aligned}
$$

The distribution function for this equation can be written as

$$
p\left(y_{t} \mid z_{t} ; \theta\right)=\frac{1}{\sqrt{2 \pi} \sigma_{a_{t}}} \exp \left\{-\frac{\left(y_{t}-x_{t} \beta_{s_{t}}\right)^{2}}{2 \sigma_{s_{t}}^{2}}\right\}
$$

The log likelihood function from the above equation is

$$
\log p\left(y_{t} \mid z_{t} ; \theta\right)=-\frac{1}{2} \log 2 \pi-\frac{1}{2} \log \sigma_{s_{t}}^{2}-\frac{\left(y_{t}-x_{t} \beta_{s_{t}}\right)^{2}}{2 \sigma_{s_{t}}^{2}}
$$

\footnotetext{
7 Untuk mengetahui optimal lag dari autoregressive akan digunakan nilai AIC dan SBC.
} 
FOC that maximaizes the log-likelihood function above is

$$
\frac{\partial \log p\left(y_{t} \mid z_{t} ; \theta\right)}{\partial \beta_{j}}=-2 \frac{y_{t}-x_{t}{ }^{\prime} \beta_{j}}{2 \sigma_{j}^{2}} x_{t}=\frac{\left(y_{t}-x_{t}{ }^{\prime} \beta_{j}\right) x_{t}}{\sigma_{j}^{2}}, s_{t}=j
$$

and

$$
\frac{\partial \log p\left(y_{t} \mid z_{t} ; \theta\right)}{\partial \sigma_{j}^{2}}=-\frac{1}{2} \frac{1}{\sigma_{j}^{2}}+\frac{\left(y_{t}-x_{t}{ }^{\prime} \beta_{j}\right)^{2}}{2 \sigma_{j}^{4}}
$$

Based on Hamilton, likelihood function from the above equation is

$$
L(\theta)=\sum_{t=1}^{T} \log p\left(y_{t} \mid z_{t} ; \theta\right)
$$

According to Hamilton (1990) the marginal distribution function of the joint distribution can be written as follows. Defined as

$$
\begin{aligned}
& Y=\left(y_{T}{ }^{\prime}, y_{T-1}{ }^{\prime}, \ldots, y_{1}{ }^{\prime}\right)^{\prime} \\
& S=\left(s_{T}, s_{T-1}, \ldots, s_{1}\right)^{\prime}
\end{aligned}
$$

Then the marginal distribution for these two events are

$$
p(Y ; \theta)=\int_{S} p(Y, S ; \theta)
$$

Then new function can be defined as the expectation of log-likelihood

$$
Q\left(\theta_{i+1} ; \theta_{i}, Y\right)=\int_{S} \log p\left(Y, S ; \theta_{i+1}\right) \cdot p\left(Y, S ; \theta_{i}\right)
$$

This function is very useful in maximizing log-likelihood. Based on Hamilton it is noted that the FOC condition will be met at the time

$$
\frac{\partial Q\left(\theta_{i+1} ; \theta_{i}, Y\right)}{\partial \theta_{i+1}}=\int_{S} \frac{\partial \log p\left(Y, S ; \theta_{i+1}\right)}{\partial \theta_{i+1}} \cdot p\left(Y, S ; \theta_{i}\right)=0
$$

Hamilton (1990) proved that the above equation satisfy the FOC which maximizes the log-likelihood function. 
Thelog-likelihood function is maximized by defining the Lagrange function as follows

$J(\theta)=L(\theta)+\lambda\left(1-\pi_{1}-\pi_{2}-\cdots-\pi_{k}\right)$

With this function will be obtained

1. $\frac{\partial J(\theta)}{\partial \beta_{j}}=\frac{\partial L(\theta)}{\partial \beta_{j}}=\sum_{t=1}^{T} \frac{p\left(y_{t}, s_{t}=j ; \theta\right)}{p\left(y_{t} ; \theta\right)} \frac{\left(y_{t}-x_{t}{ }^{\prime} \beta_{j}\right) x_{t}}{\sigma_{j}^{2}}$

$$
=\sum_{t=1}^{T} \frac{\left(y_{t}-x_{t}^{\prime} \beta_{j}\right) x_{t}}{\sigma_{j}^{2}} p\left(s_{t} \mid y_{t} ; \theta\right)=0
$$

Multiplied by the divisor 0 then

$$
\sum_{t=1}^{T}\left(y_{t}-x_{t}{ }^{\prime} \beta_{j}\right) x_{t} p\left(s_{t}=j \mid y_{t} ; \theta\right)=0
$$

This equation can be solved by

$$
\begin{aligned}
& \sum_{t=1}^{T} y_{t} x_{t} p\left(s_{t}=j \mid y_{t} ; \theta\right)-\beta_{j} \sum_{t=1}^{T} x_{t}{ }^{\prime} x_{t} p\left(s_{t}=j \mid y_{t} ; \theta\right)=0 \\
& \hat{\beta}_{j}=\left[\sum_{t=1}^{T} x_{t}{ }^{\prime} x_{t} p\left(s_{t}=j \mid y_{t} ; \theta\right)\right]^{-1} \sum_{t=1}^{T} y_{t} x_{t} p\left(s_{t}=j \mid y_{t} ; \theta\right) \\
& \hat{\beta}_{j}=\left[\sum_{t=1}^{T} x_{t}{ }^{*}{ }^{\prime} x_{t}^{*}\right]^{-1} \sum_{t=1}^{T} x_{t}^{*} y_{t}^{*}
\end{aligned}
$$

With $x_{t}^{*}=x_{t} \sqrt{p\left(s_{t}=j \mid y_{t} ; \theta\right)} \quad y_{t}^{*}=y_{t} \sqrt{p\left(s_{t}=j \mid y_{t} ; \theta\right)}$

2. $\frac{\partial}{\partial \sigma_{j}^{2}} J(\theta)=\frac{\partial}{\partial \sigma_{j}^{2}} L(\theta)=\sum_{t=1}^{T} \frac{p\left(y_{t}, s_{t}=j ; \theta\right)}{p\left(y_{t} ; \theta\right)}\left\{-\frac{1}{2 \sigma_{j}^{2}}+\frac{\left(y_{t}-x_{t}{ }^{\prime} \beta_{j}\right)^{2}}{2 \sigma_{j}^{4}}\right\}$

$$
=\sum_{t=1}^{T}\left\{-\frac{1}{2 \sigma_{j}^{2}}+\frac{\left(y_{t}-x_{t}^{\prime} \beta_{j}\right)^{2}}{2 \sigma_{j}^{4}}\right\} p\left(s_{t}=j \mid y_{t} ; \theta\right)=0
$$


If the equation is solved then we will get

$$
\begin{aligned}
& \hat{\sigma}_{j}^{2}=\frac{\sum_{t=1}^{T}\left(y_{t}-x_{t}{ }^{\prime} \hat{\beta}_{j}\right)^{2} p\left(s_{t}=j \mid y_{t} ; \theta\right)}{\sum_{t=1}^{T} p\left(s_{t}=j \mid y_{t} ; \theta\right)} \\
& \text { 3. } \frac{\partial}{\partial \pi_{j}} J(\theta)=\frac{\partial}{\partial \pi_{j}} L(\theta)=\sum_{t=1}^{T} \frac{p\left(y_{t}, s_{t}=j ; \theta\right)}{p\left(y_{t} ; \theta\right)}-\lambda \\
& =\sum_{t=1}^{T} \frac{p\left(y_{t} \mid s_{t}=j ; \theta\right) p\left(s_{t}=j ; \theta\right)}{p\left(y_{t} ; \theta\right)}-\lambda=0 \\
& s_{t}=j \Rightarrow p\left(s_{t}=j ; \theta\right)=1
\end{aligned}
$$

If the equation is solved, it will get

$$
\sum_{t=1}^{T} \frac{p\left(y_{t} \mid s_{t}=j ; \theta\right)}{p\left(y_{t} ; \theta\right)}-\lambda=\pi_{j}^{-1} \sum_{t=1}^{T} \frac{p\left(y_{t}, s_{t}=j ; \theta\right)}{p\left(y_{t} ; \theta\right)}-\lambda=\pi_{j}^{-1} \sum_{t=1}^{T} p\left(s_{t}=j \mid \theta\right)-\lambda=0
$$

If simplified, the following is obtained

$$
\sum_{t=1}^{T} p\left(s_{t}=j \mid \theta\right)=\lambda \pi
$$

The sum for $j=1,2, \ldots, k$, is then obtainedto get

$$
\begin{aligned}
& \sum_{t=1}^{T} \sum_{j=1}^{K} p\left(s_{t}=j \mid \theta\right)=\lambda \sum_{j=1}^{K} \pi_{j} \\
& \sum_{t=1}^{T}\{1\}=\lambda .1 \Rightarrow \lambda=T
\end{aligned}
$$

Because. $\sum_{j=1}^{K} p\left(s_{t}=j \mid \theta\right)=1$ dan $\sum_{j=1}^{K} \pi_{j}=1$ So its estimator can be written

$$
\hat{\pi}_{j}=\frac{1}{T} \sum_{t=1}^{T} p\left(s_{t}=j \mid \theta\right)
$$

According to Hamilton (1990) it can be proved that the following transition probabilities satisfy FOC. Then the transition probabilities can be shown by the following equation 


$$
p_{i j}^{n+1}=\frac{\sum_{t=1}^{T} p\left(s_{t}=j, s_{t-1}=i \mid y_{t} ; \theta\right)}{\sum_{t=1}^{T} p\left(s_{t-1}=i \mid y_{t} ; \theta\right)}
$$

From Hamilton (1990) an algorithm is then used to estimate the parameters of the arbitrary initial value.

$$
\begin{aligned}
p\left(y_{t} \mid Y_{t-1}\right) & =\sum_{s_{t}=1}^{K} \sum_{s_{t-1}=1}^{K} p\left(s_{t} \mid s_{t-1}\right) p\left(y_{t} \mid s_{t}\right) \rho_{s_{t-1}} \\
p\left(s_{t}, s_{t-1} \mid y_{t}\right) & =\frac{p\left(s_{t} \mid s_{t-1}\right) p\left(y_{t} \mid s_{t}\right) p\left(s_{t-1} \mid y_{t-1}\right)}{p\left(y_{t} \mid Y_{t-1}\right)} \\
& =\frac{p\left(s_{t} \mid s_{t-1}\right) p\left(y_{t} \mid s_{t}\right) \rho_{s_{t-1}}}{p\left(y_{t} \mid Y_{t-1}\right)} \\
p\left(s_{t-1} \mid y_{t}\right) & =\sum_{s_{t}=1}^{K} p\left(s_{t}, s_{t-1} \mid y_{t}\right)
\end{aligned}
$$

$\rho_{s_{t-1}}=p\left(s_{t-1} \mid y_{t-1}\right)$ taken from the previous value as the initial value $\rho_{s o}=p($ solyo $)$. This value is taken as the initial value of any parameter estimation.

For the case of a two-state markov change regime as used in this paper, the value of the transition probability is calculated as follows.

$$
\begin{gathered}
p_{11}^{n+1}=\frac{\sum_{t=1}^{T} p\left(s_{t}=1, s_{t-1}=1 ; \theta\right)}{\sum_{t=1}^{T} p\left(, s_{t-1}=1 ; \theta\right)} \\
p\left(s_{t}=1, s_{t-1}=1 \mid y_{t}\right)=\frac{p\left(s_{t}=1 \mid s_{t-1}=1\right) p\left(y_{t} \mid s_{t}=1\right) p\left(s_{t-1}=1 \mid y_{t-1}\right)}{p\left(y_{t} \mid Y_{t-1}\right)} \\
p\left(s_{t}=2, s_{t-1}=1 \mid y_{t}\right)=\frac{p\left(s_{t}=2 \mid s_{t-1}=1\right) p\left(y_{t} \mid s_{t}=2\right) p\left(s_{t-1}=1 \mid y_{t-1}\right)}{p\left(y_{t} \mid Y_{t-1}\right)}
\end{gathered}
$$




$$
\begin{aligned}
& p\left(s_{t}=1, s_{t-1}=1 \mid y_{t}\right)=\frac{p_{11}^{n} \eta_{t \mid s_{t}=1} \rho_{s_{t-1}}^{n}}{p\left(y_{t} \mid Y_{t-1}\right)} \\
& {\left[\begin{array}{ll}
p\left(s_{t}=1, s_{t-1}=1 \mid y_{t}\right) & p\left(s_{t}=2, s_{t-1}=1 \mid y_{t}\right) \\
p\left(s_{t}=1, s_{t-1}=2 \mid y_{t}\right) & p\left(s_{t}=2, s_{t-1}=2 \mid y_{t}\right)
\end{array}\right]} \\
& \left.\quad\left\{\begin{array}{cc}
\rho_{s_{0}=1} & 0 \\
0 & \rho_{s_{0}=2}
\end{array}\right]\left[\begin{array}{ll}
p_{11} & p_{12} \\
p_{21} & p_{22}
\end{array}\right]\left[\begin{array}{cc}
\eta_{t \mid s_{t}=1} & 0 \\
0 & \eta_{t \mid s_{t}=2}
\end{array}\right]\right\}
\end{aligned}
$$

$p\left(y_{t} \mid Y_{t-1}\right)=\sum_{s_{t}=1}^{K} \sum_{s_{t-1}=1}^{K} p_{i j}^{n} \eta_{t \mid s_{t}} \rho_{s_{t-1}}^{n}=\left[\begin{array}{ll}\rho_{s_{0}=1} & \rho_{s_{0}=2}\end{array}\right]\left[\begin{array}{ll}p_{11} & p_{12} \\ p_{21} & p_{22}\end{array}\right]\left[\begin{array}{l}\eta_{t \mid s_{t}=1} \\ \eta_{t \mid s_{t}=2}\end{array}\right]$

$p\left(s_{t-1}=1 \mid y_{t}\right)=\sum_{s_{t}=1}^{K} p\left(s_{t}, s_{t-1}=1 \mid y_{t}\right)$

$$
p\left(s_{t-1}=1 \mid y_{t}\right)=p\left(s_{t}=1, s_{t-1}=1 \mid y_{t}\right)+p\left(s_{t}=2, s_{t-1}=1 \mid y_{t}\right)
$$

$p\left(s_{t-1}=1 \mid y_{t}\right)=\frac{\left[p\left(s_{t}=2 \mid s_{t-1}=1\right) p\left(y_{t} \mid s_{t}=2\right)+p\left(s_{t}=1 \mid s_{t-1}=1\right) p\left(y_{t} \mid s_{t}=1\right)\right] p\left(s_{t-1}=1 \mid y_{t-1}\right)}{p\left(y_{t} \mid Y_{t-1}\right)}$

$$
=\frac{\left[p_{12} \eta_{t \mid s_{t}=2}+p_{11} \eta_{t \mid s_{t}=1}\right] p\left(s_{t-1}=1 \mid y_{t-1}\right)}{p\left(y_{t} \mid Y_{t-1}\right)}
$$

$$
\begin{aligned}
& {\left[\begin{array}{l}
p\left(s_{t-1}=1 \mid y_{t}\right) \\
p\left(s_{t-1}=2 \mid y_{t}\right)
\end{array}\right]=\left[\begin{array}{ll}
p\left(s_{t}=1, s_{t-1}=1 \mid y_{t}\right) & p\left(s_{t}=2, s_{t-1}=1 \mid y_{t}\right) \\
p\left(s_{t}=1, s_{t-1}=2 \mid y_{t}\right) & p\left(s_{t}=2, s_{t-1}=2 \mid y_{t}\right)
\end{array}\right]\left[\begin{array}{l}
1 \\
1
\end{array}\right]} \\
& =\left[\begin{array}{l}
p\left(s_{t}=1, s_{t-1}=1 \mid y_{t}\right)+p\left(s_{t}=2, s_{t-1}=1 \mid y_{t}\right) \\
p\left(s_{t}=1, s_{t-1}=2 \mid y_{t}\right)+p\left(s_{t}=2, s_{t-1}=2 \mid y_{t}\right)
\end{array}\right] \\
& p_{11}^{n+1}=\frac{\sum_{t=1}^{T} \frac{p_{11} \eta_{t \mid s_{t}=1} p\left(s_{t-1}=1 \mid y_{t-1}\right)}{p\left(y_{t} \mid Y_{t-1}\right)}}{\sum_{t=1}^{T} \frac{\left(p_{12} \eta_{t \mid s_{t}=2}+p_{11} \eta_{t \mid s_{t}=1}\right) p\left(s_{t-1}=1 \mid y_{t-1}\right)}{p\left(y_{t} \mid Y_{t-1}\right)}} \\
& =\left[\begin{array}{ll}
p\left(s_{t}=1, s_{t-1}=1 \mid y_{t}\right) & p\left(s_{t}=2, s_{t-1}=1 \mid y_{t}\right) \\
p\left(s_{t}=1, s_{t-1}=2 \mid y_{t}\right) & p\left(s_{t}=2, s_{t-1}=2 \mid y_{t}\right)
\end{array}\right] \text {. }
\end{aligned}
$$

$$
\left[\begin{array}{cc}
{\left[p\left(s_{t}=1, s_{t-1}=1 \mid y_{t}\right)+p\left(s_{t}=2, s_{t-1}=1 \mid y_{t}\right)\right]^{-1}} & 0 \\
0 & {\left[p\left(s_{t}=1, s_{t-1}=2 \mid y_{t}\right)+p\left(s_{t}=2, s_{t-1}=2 \mid y_{t}\right)\right]^{-1}}
\end{array}\right]
$$


Where $p\left(s_{t}=1 \mid s_{t-1}=1\right)$ is obtained from the transition matrix while $p\left(y_{t} \mid s_{t}=1\right)$ from the equation of conditional distribution. The initial value used is $p\left(s_{0}=1 \mid y_{0}\right)$. The same way can also be used to for estimating the magnitude $p_{22}$. The initial values used to estimate the magnitude of the parameters are.

$$
\left\{\alpha_{1}, \alpha_{2}, \phi_{1,1}, \phi_{2,1}, \phi_{3,1}, \phi_{1,2}, \phi_{2,2}, \phi_{3,2}, p_{11}, p_{22}, \rho_{1}, \rho_{2}, \sigma_{1}^{2}, \sigma_{2}^{2}\right\}
$$




\section{APPENDIX 2}

\section{Changes in Fund and Bank to Bank Run Ergodic Probability State}

\section{State Bank (BP)}
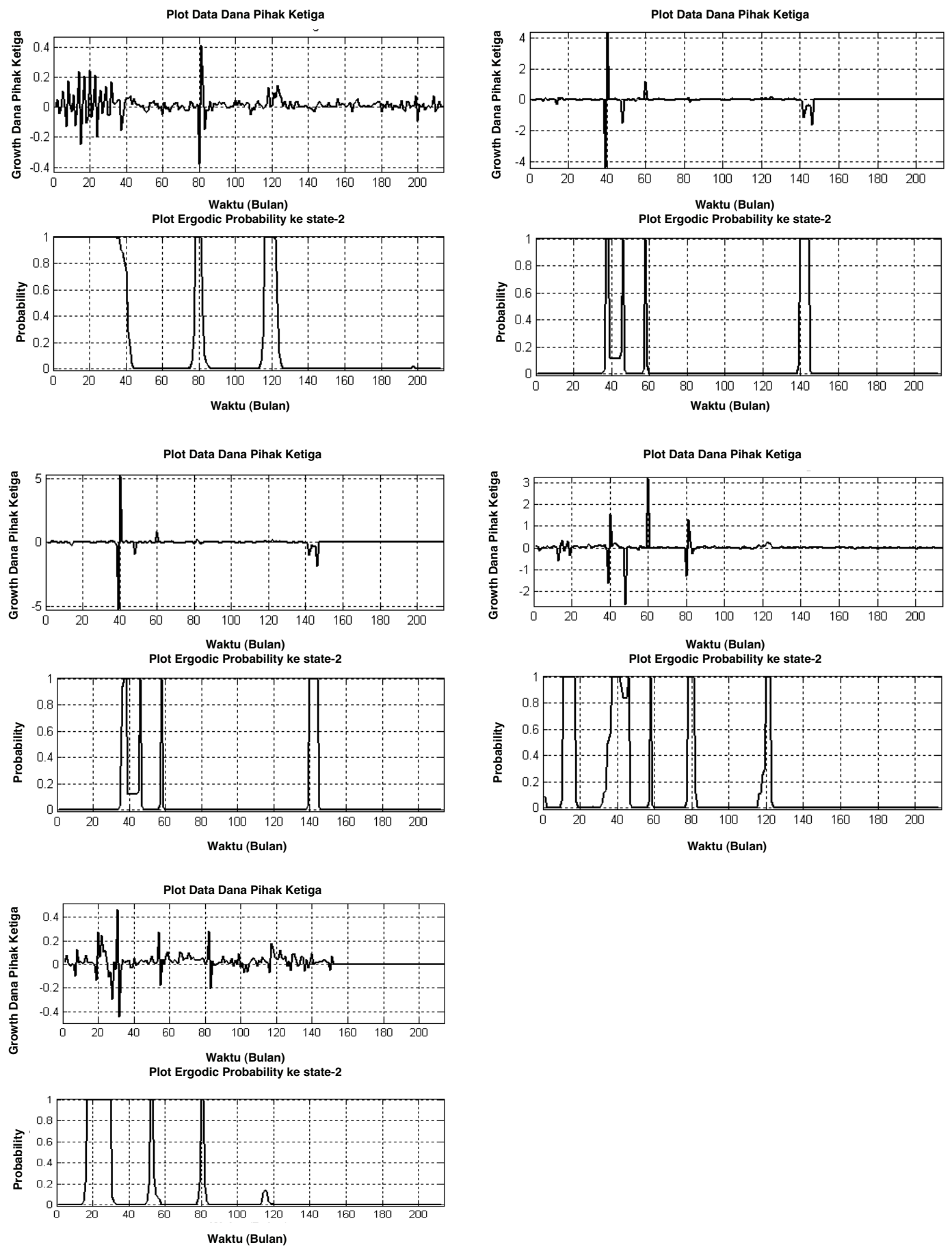


\section{Private Forex Bank (BSD)}
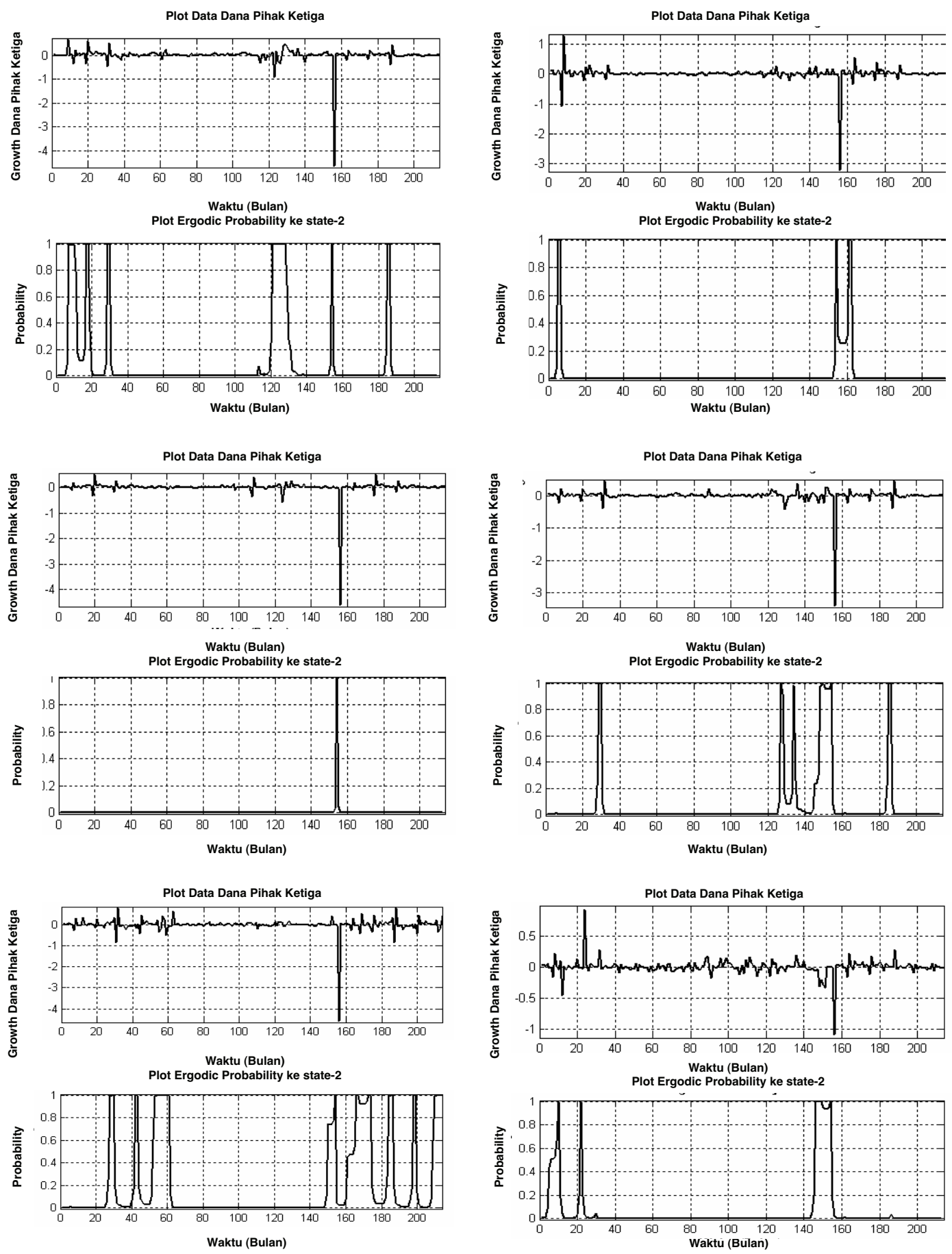

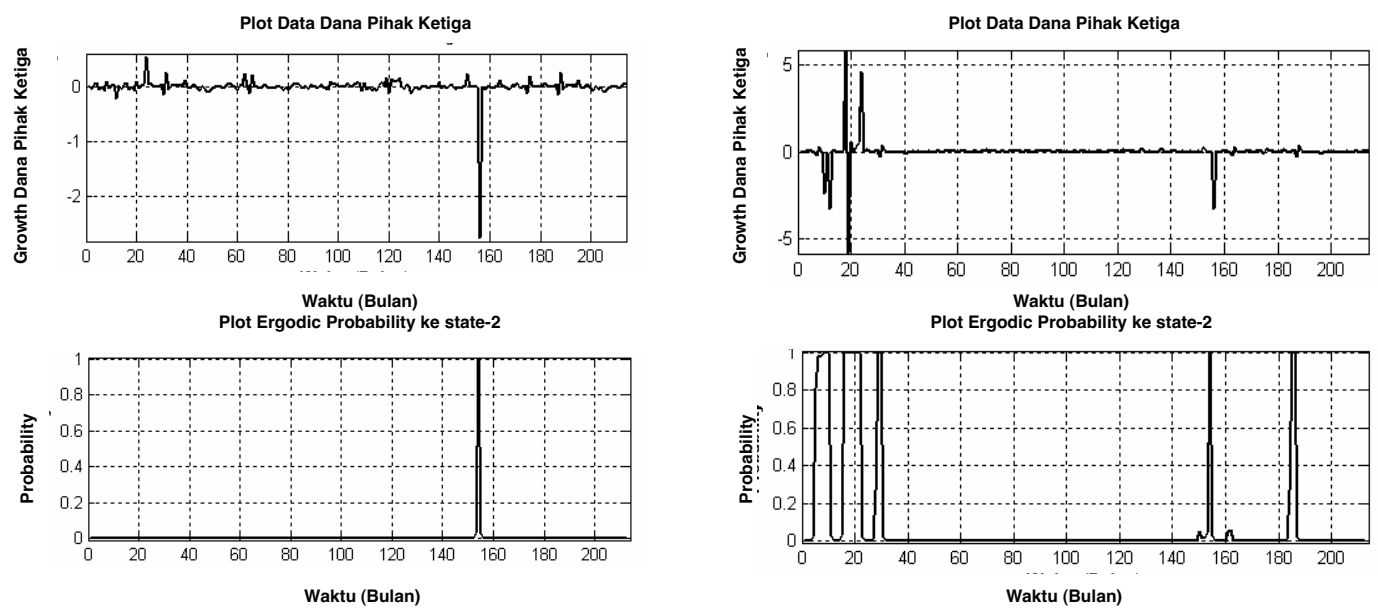

\section{Pivate Non-Forex Bank (BSND)}
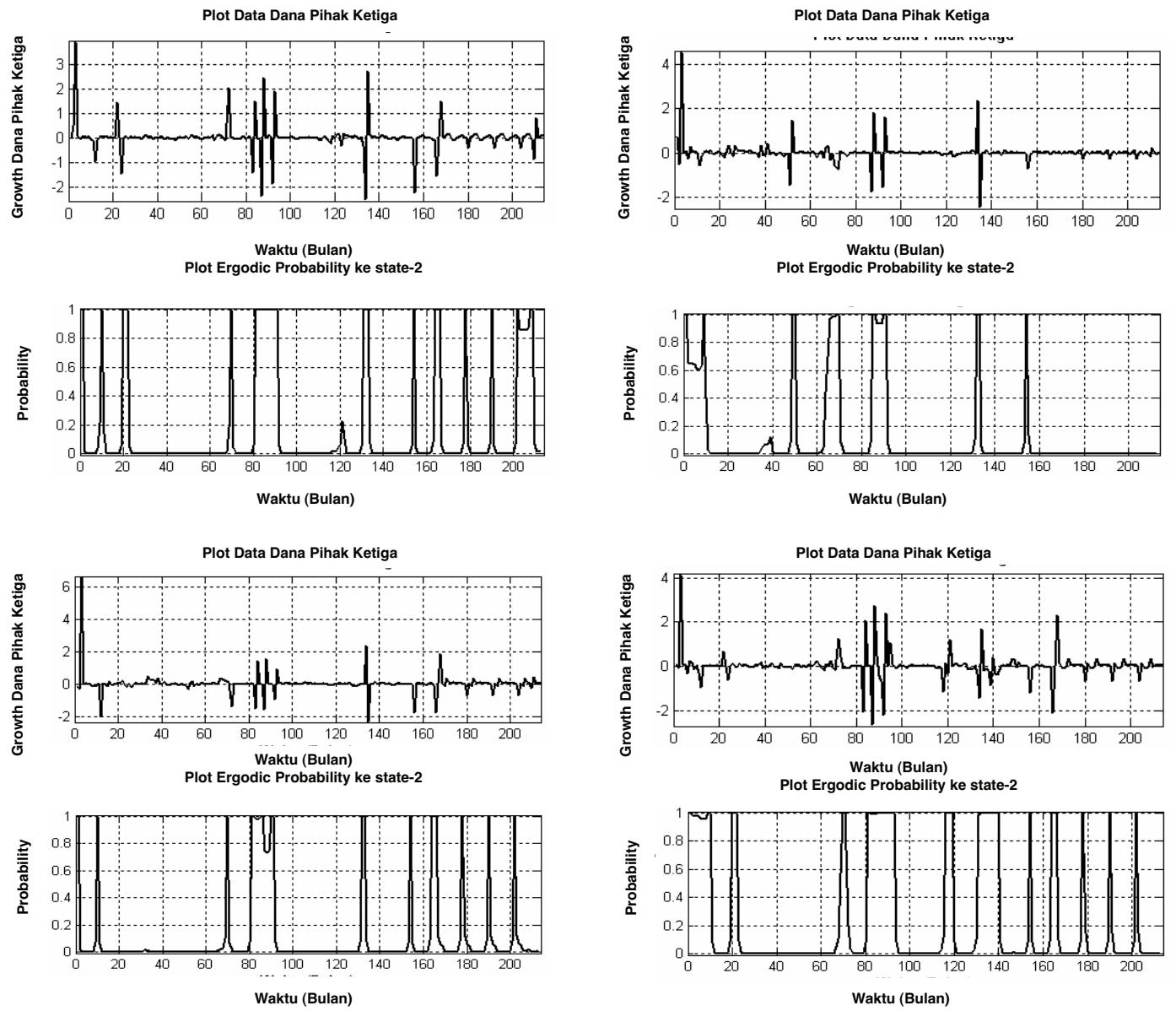

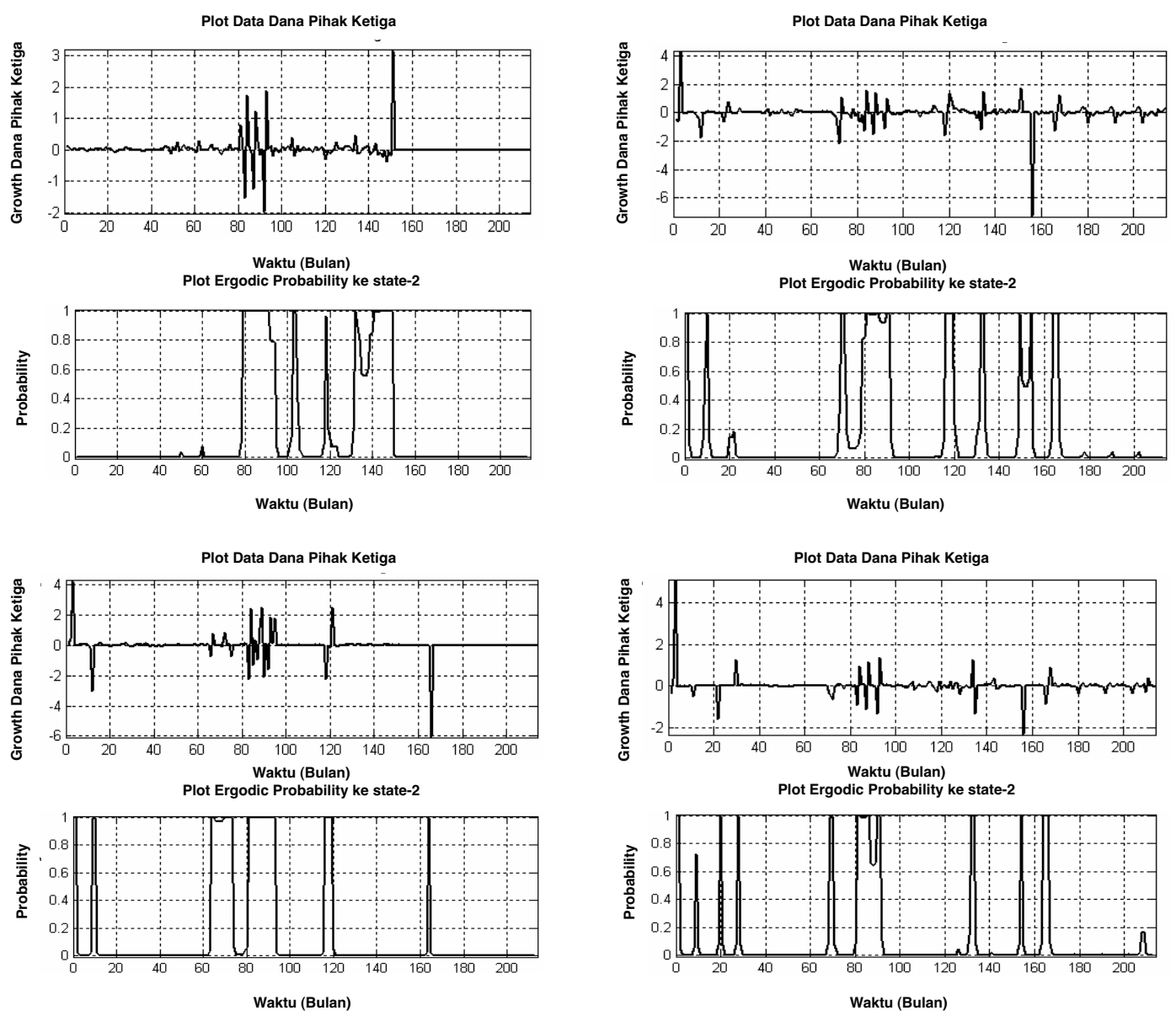

\section{Foreign Bank (BA)}
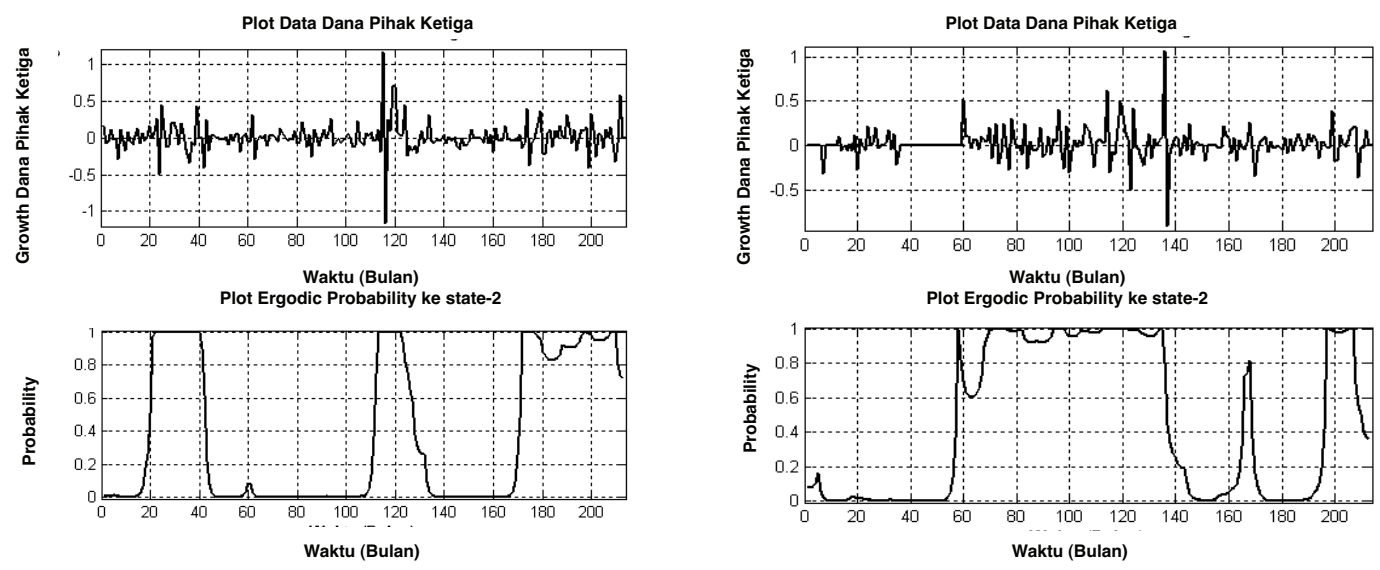

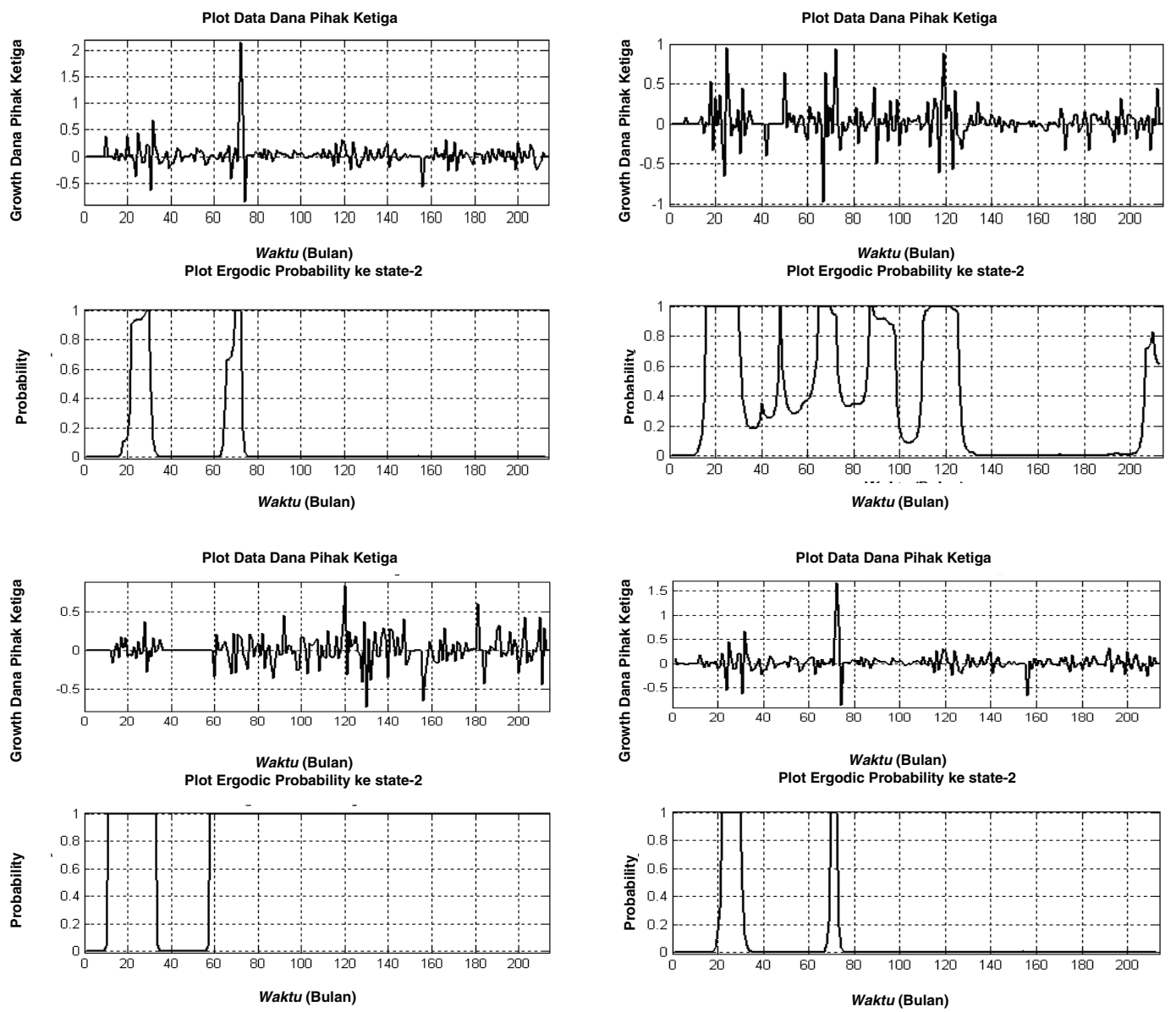

\section{Mix Bank (BC)}
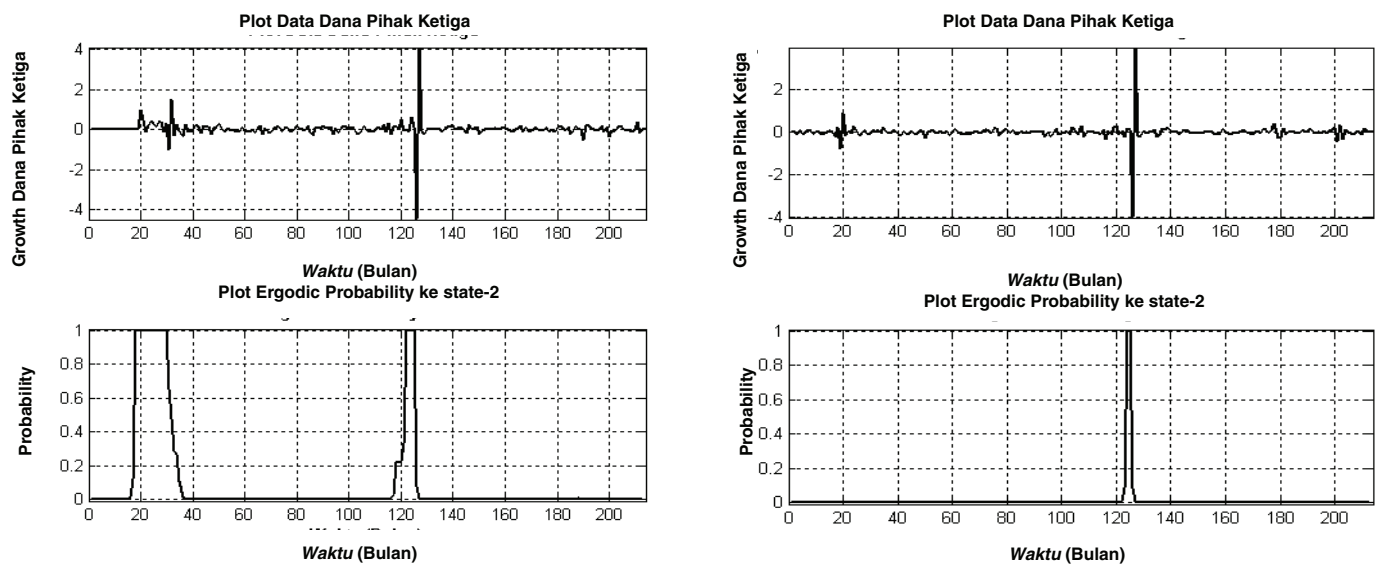

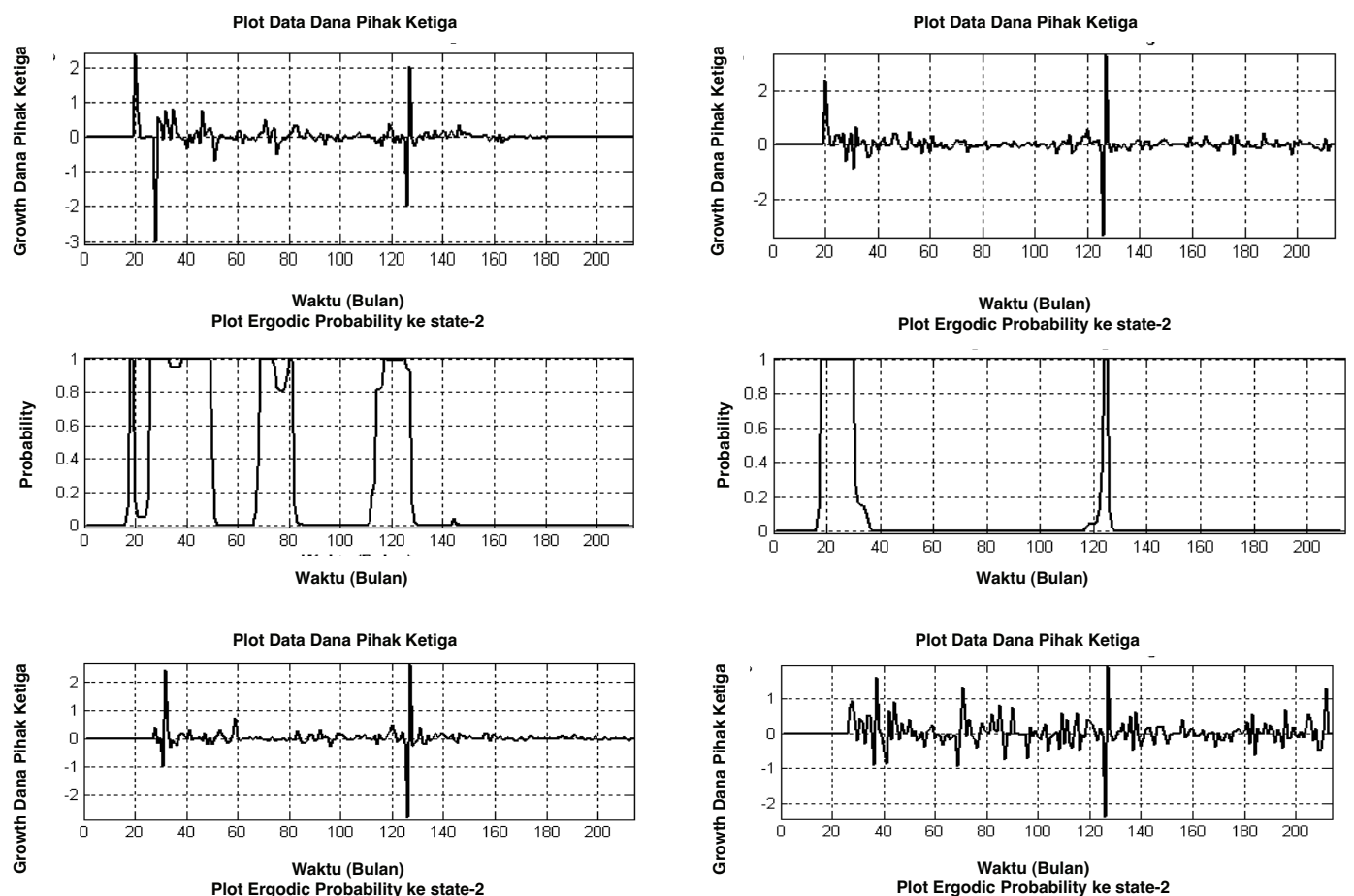

Plot Ergodic Probability ke state-2
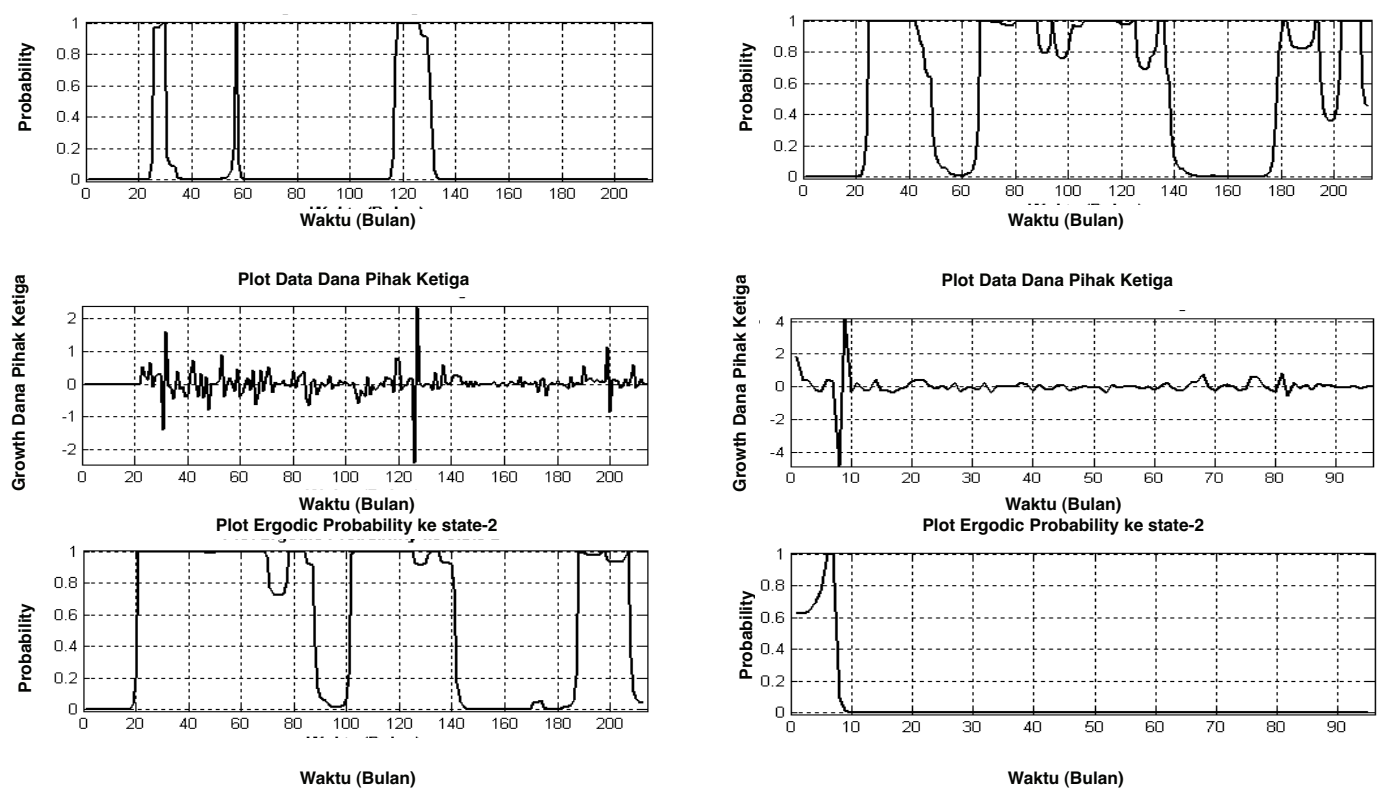


\section{Bank with Frozen Business Activity (BBKU)}
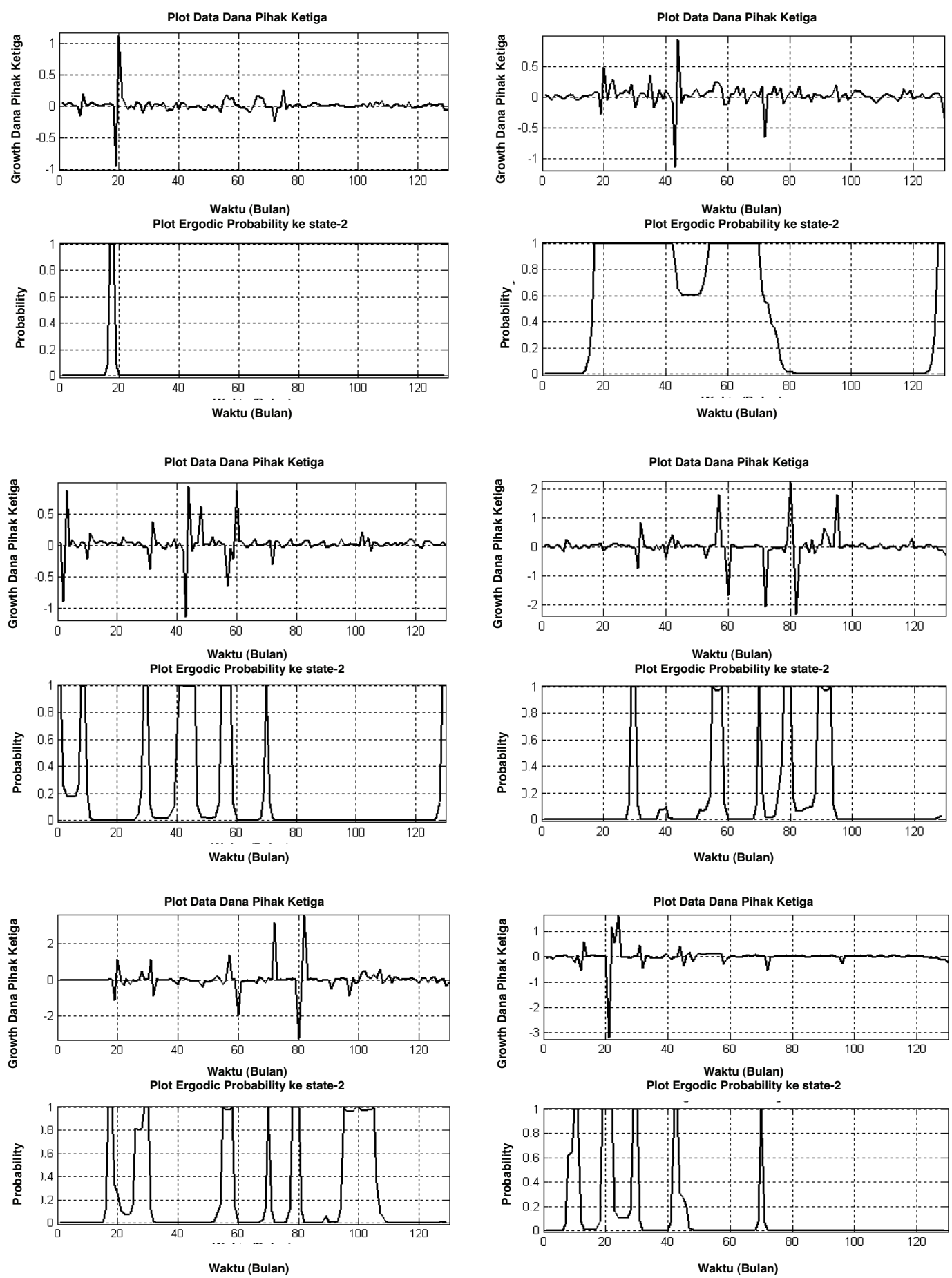


\section{Bank with Frozen Operation (BBO)}
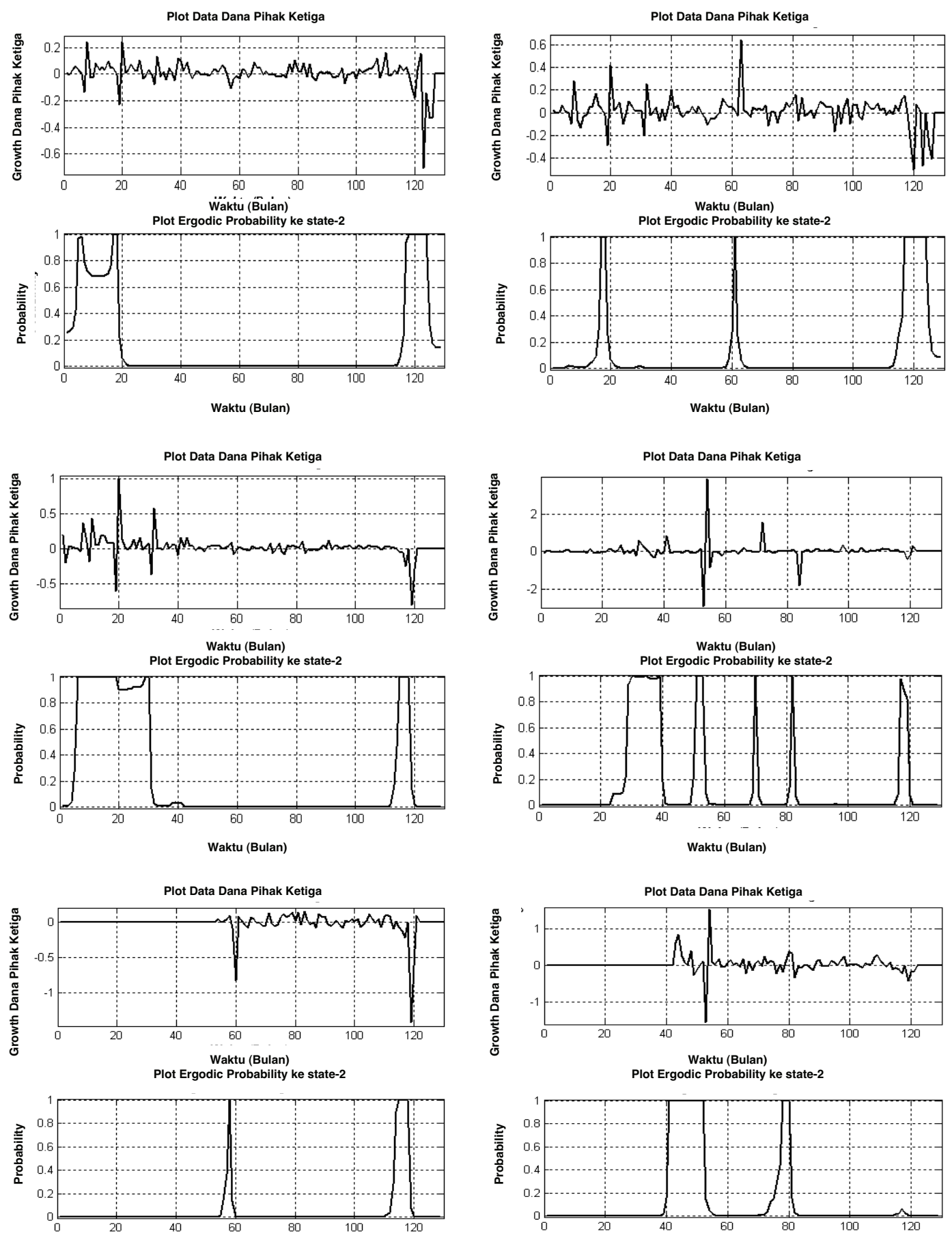

Waktu (Bulan)

Waktu (Bulan) 
This page is intentionally left blank 